\title{
Modulatory Effect of Dietary Copper Nanoparticles and Vitamin C Supplementations on Growth Performance, Hematological and Immune Parameters, Oxidative Status, Histology, and Disease Resistance Against Yersinia Ruckeri in Rainbow Trout (Oncorhynchus Mykiss)
}

Mojtaba Delavari

University of Zabol

Ahmad Gharaei ( $\nabla$ agharaei551@gmail.com )

University of Zabol https://orcid.org/0000-0002-0942-0592

Javad Mirdar Harijani

University of Zabol

Aida Davari

University of Zabol

Abolhasan Rastiannasab

University of Zabol

Research Article

Keywords: Antioxidant capacity, Resistance to pathogen, Copper nanoparticle, Vitamin C, Growth performance

Posted Date: April 29th, 2021

DOI: https://doi.org/10.21203/rs.3.rs-214260/v1

License: (c) (i) This work is licensed under a Creative Commons Attribution 4.0 International License. Read Full License

Version of Record: A version of this preprint was published at Fish Physiology and Biochemistry on November 30th, 2021. See the published version at https://doi.org/10.1007/s10695-021-01036-2. 


\section{Abstract}

The present study aimed to evaluate the effects of dietary copper nanoparticles (Cu-NPs) and vitamin C (VC) supplementations on rainbow trout (Oncorhynchus mykiss) juveniles. Six trial diets were supplemented with Cu-NPs and VC including 0/0 (T1, control diet), 0/250 (T2), 0/500 (T3), 2/250 (T4), 2/500 (T5), and 2/0 (T6) mg Cu-NPs/VC per kg diet. After the feeding trial for 60 days, the fish were challenged with Yersinia ruckeri and the survival rate was calculated for 15 days. Based on the data analysis, weight gain (WG), feed conversion ratio (FCR), specific growth rate (SGR), protein efficiency ratio (PER), lysozyme, alternative complement activity (ACH50), catalase (CAT), glutathione peroxidase (GPX), hematocrit (Hct) and mean corpuscular volume (MCV) were significantly $(p<0.05)$ affected by the Cu-NPs factor. Meanwhile, VC was a significant factor for hemoglobin $(\mathrm{Hb})$ and superoxide dismutase (SOD) $(p<$ 0.05). The results showed that the Cu-NPs and/or VC-supplemented diets improved WG, FCR, SGR, PER, lysozyme, ACH50, SOD, CAT, GPX, Hb, Hct, and MCV when compared with the control group $(p<0.05)$. The expressions of TNF-a, IL-1ß, IL-10, SOD, CAT, and GPX genes were significantly $(p<0.05)$ decreased in the fish fed on T3, T4, and T5 diets versus the control. In addition, the dietary Cu-NPs and VC supplementations significantly enhanced resistance against pathogens and led to the control of infection in rainbow trout. In conclusion, Cu-NPs and VC administered as feed additive at $2 / 250-500 \mathrm{mg} / \mathrm{kg}$ elevated the growth performance, antioxidant capacity, and health of rainbow trout.

\section{Introduction}

A key factor of aquaculture viability in all rearing systems is optimal nutrition. Mineral supplements, such as copper, are used to improve growth and food metabolism, strengthen the immune system and antioxidant capacity, and regulate ion exchange and osmotic balance (El Basuini et al. 2016; Mohseni et al. 2014; Lin et al. 2008).

Copper is an essential trace element that is involved in various physiological and biological processes in fish. It plays an essential role in the structure of liver enzymes, melanin and skin pigments, bone and connective tissue formation, myelin maintenance in the nervous system, and hemoglobin synthesis (Havar and Hardy 2002; El Basuini et al. 2016). Many studies have investigated the effective role of dietary copper concentrations and types on various fish species including Penaeus vannamei (Davis et al. 1993), $P$. monodon (Lee and Shiau 2002), Oreochromis niloticus (El Shaiu et al. 2003), Haliotis discus hannai (Wang et al. 2009), Ctenopharyngodon idella (Tang et al. 2013), Huso huso (Mohseni et al. 2014) and Pagrus major (El Basuini et al. 2016).

Nanoparticle forms of essential elements have been shown to be more effective and beneficial than their traditional forms in biological systems through promoting bioavailability, thereby facilitating uptake and utilization (El Basuini et al. 2016; Gharaei et al. 2020a). Nanometer dimensions, large active surface, multiple active centers, and greater catalytic efficiency improve bioavailability and some functional aspects of these metals (Izquier et al. 2016; Rather et al. 2011). Copper nanoparticles (Cu-NPs) are a new form of the copper source that has widely been used in dietary supplementation in aquatic nutrition (EI Basuini et al. 2016; Wang et al. 2015). 
Vitamin C (VC) or ascorbic acid is a vital water-soluble micronutrient that is essential for physiological functions in animals, including aquatic animals (Fraealossi et al. 2001; Grosso et al. 2013). Vitamin C cannot be synthesized from D-glucose due to the lack of L-gluconolactone oxidase and must be obtained from exogenous sources (Wahli et al. 2003; Chahardeh Baladehi et al. 2017). VC, as a cofactor of many enzymes, plays a role in synthesizing collagen, tyrosine, cartilage, and endothelium of vessels, iron metabolism, and hematology, improving growth and reproduction, strengthening the antioxidant and immune system, and improving survival rates in aquatic animal (Combs 2008; Dawood and Koshio 2016). Some previous research has shown that a high level of $\mathrm{VC}$ can play a vigorous inhibitor role in contrast with $\mathrm{Cu}$ absorption and/or enzymatic depend on $\mathrm{Cu}$ lead to iron utilization decreasing and results iron toxicity (Pekiner and Nebiogliu 1994). Additionally, it is established that dietary VC can decrease the risk of $\mathrm{Cu}$ toxicity and Cu supplementation reduces the risk of hypervitaminosis (Watts 1989). In a review paper, Dawood and Kushio (2016) state that VC requirements in aquatic animal species depend on species, size, and feeding behavior.

Although extensive research has addressed the effect of VC supplementation, there is limited knowledge on the interaction of VC and Cu-NPs in fish. Therefore, the present study aimed to assess the effect of dietary VC and/or Cu-NP supplements on growth performance, hematological indices, antioxidant status, histological parameters, immune response, expression of some important genes like TNF-a, IL-1b, and IL10 in kidney and disease resistance against $Y$. ruckeri in juvenile rainbow trout as one of the most important aquaculture species in the Pacific Ocean in Asia and North America.

\section{Materials And Methods 2.1Experimental diets}

The basal diet formulation is presented in Table 1. The results of the chemical analysis of the trial diets are shown in Table 2. Cu-NPs (Sigma-Aldrich, $99 \%$ purity, NPs size $<75 \mu \mathrm{m}$ ) was used as the Cu source, and Stay-C (L-ascorbyl-2-mono phosphate-Ca/Na, Cayman Co., 95\% purity) as the VC source. Six trial diets were prepared including two levels of Cu-NPs ( 0 and $2 \mathrm{mg} \mathrm{kg}^{-1} \mathrm{dry}$ feed) (El Bausini et al. 2016) and three levels of VC $\left(0,250\right.$, and $500 \mathrm{mg} \mathrm{kg}^{-1}$ dry feed) (Dawood et al. 2016) (the control diet without Cu-NPs and/or VC (T1), T2, T3, T4, T5, and T6). They were supplemented to the basal diet according to a 213 factorial design. In preparing the trial diets, ingredients were mixed in a blender for $15 \mathrm{~min}$. The Cu source was mixed with the lipid sources for $15 \mathrm{~min}$ and then added to the other ingredients. In the next step, the premixed ingredients were mixed with water and then passed through a meat grinder to prepare pellets with $2 \mathrm{~mm}$ diameter, which were dried on nylon screens at $45^{\circ} \mathrm{C}$ and kept in two-layer plastics at $-20^{\circ} \mathrm{C}$ until they were consumed. The actual concentration of proximate composition of $\mathrm{Cu}$ and $\mathrm{VC}$ was measured in each diet (Table 2).

\subsection{Treatments and sample collection}


Juvenile rainbow trout were taken from a reproduction center (Shahid Motahari, Yasouj, Iran), transported alive to the laboratory, and acclimated to the experimental conditions for two weeks prior to the beginning of the feeding trial. The fish (initial average weight $15.1 \pm 1.05 \mathrm{~g}$ ) were randomly distributed into six groups with triplicate tanks within each group ( 18 tanks ( $200 \mathrm{~L}$ of each) and 12 fish per tank). During 60 days, the fish were fed with various test diets three times a day at 08:00, 13:00, and 18:00 based on $3 \%$ of the body weight. The quality of water during the experimental period including, temperature, $\mathrm{pH}$, and dissolved oxygen were recorded to be $16 \pm 2^{\circ} \mathrm{C}, 7.1 \pm 0.3$, and $6.4 \pm 0.2 \mathrm{mg} \mathrm{l}^{-1}$, respectively. At the end of the trial, the fish fasted, and their growth performance, weight gain (WG\%), specific growth rate (SGR\%), feed conversion ratio (FCR), survival rate (\%), and protein efficiency ratio (PER) were measured by the following equations (Jafarinejad et al. 2018):WG \% = (final body weight (g) -initial body weight $(\mathrm{g})$ ) $\times 100 \mathrm{SGR} \%=$ ( $\mathrm{Ln}$ final body weight $(\mathrm{g})$-Ln initial body weight) $\times 100 /$ experimental daysFCR $=$ dry feed fed $/$ wet weight gainPER $\%=[($ final body weight $(\mathrm{g})$ - initial body weight $(\mathrm{g})) /$ dry protein intake $(\mathrm{g})] \times 100$ Survival rate $\%=$ (final number of fish/ initial number of fish) $\times 100$

\subsection{Hematological and biochemical measurement}

Blood was collected from the caudal vein of three fishes from each tank by a non-heparinized syringe (3 $\mathrm{ml}$ ) for hematological analysis. Afterward, partial whole blood was introduced into heparinized microtubes and used to measure red blood cell (RBC), white blood cell (WBC), hematocrit (Hct), hemoglobin ( $\mathrm{Hb})$, mean corpuscular hemoglobin ( $\mathrm{MCH}$ ), mean corpuscular hemoglobin concentration (MCHC), and mean corpuscular volume (MCV) by the procedures described in Gharaei et al. (2020b) and Adel and Khara (2016). For biochemical analysis, blood sera were separated by centrifuging at $3000 \mathrm{rpm}$ for $10 \mathrm{~min}$ (Gharaei et al., 2010). Catalase (CAT), superoxide dismutase (SOD), glutathione peroxidase (GPX), and malondialdehyde (MDA) ( $n=6$ from each group) in serum samples were measured with a commercial chemical calorimetric enzyme assay kit (ZellBio $\mathrm{GmbH}$, Germany) by the procedures described in Gharaei et al. (2020b). The lysozyme activity in serum samples was assayed using the method of Ellis (1990) and Gharaei et al. (2020b). Alternative complement activity (ACH50) in serum samples was assessed using the protocol presented by Yano (1992).

\subsection{Measurement of gene expression}

To compare mRNA expression levels, the posterior parts of the intestinal tissues from each treatment group $(\mathrm{N}=5)$ were randomly collected at the end of the trial, frozen, and kept at $-80^{\circ} \mathrm{C}$ until use. Total RNA extraction was carried out in the intestinal samples by using the Takapou Zist Kit (Tehran, Iran) following the manufacturer's instructions. RNA integrity was verified by ethidium bromide staining of the $28 \mathrm{~S}$ and 18 ribosomal RNA bands (as a marker) on $1.2 \%$ agarose gel. To remove DNA contaminants, the extracted RNA was treated with RNA-free DNase (Takara, Japan), and the reverse was transcribed to cDNA by a superscript cDNA synthesis kit (AccuPawer ${ }^{\circledR}$ CycleScript RT PreMix, Germany) following the manufacturer's instructions. The mRNA expression levels of CAT, SOD, GPX, TNF-a, IL-1 $\beta$, and IL-10 genes in the intestinal of the rainbow trout were evaluated by fluorescent real-time quantitative PCR. The specific 
primers for CAT, SOD, GPX, TNF-a, IL-1 $\beta$, IL-10, and $\beta$-actin (housekeeping gene) were designed according to the cDNA sequences of rainbow trout in GenBank (Nootash et al. 2013; Hosseini et al. 2020) and thermocycling conditions as indicated in Table 3. All primers were synthesized by TakapouZist Co., Ltd. and amplified fragments length of 70-295 bp. Real-time quantitative PCR was conducted in a quantitative thermal cycler (Mastercycler ${ }^{\circledR}$ eprealplex, Eppendorf, Germany). Three replicates were performed for each sample. The threshold cycle (CT) was determined manually for each run. The PCR efficiency of each set of primers was determined using serial 10 -fold dilutions of CDNA, and resulting plots of CT vs. the logarithmic cDNA dilution, using the efficiency equation $(E)$ :

$E=10^{(-1 / \text { slope })}$

Gene expression data were analyzed using the $2^{-\Delta \Delta C T}$ method after it was verified that the primers were amplified with an efficiency of $97-99 \%$ (Gharaei et al. 2011). The data for all treatment groups were compared to the control group.

\subsection{Bacterial challenge test}

At the end of the experiment period, the survivals of fish in each treated group were challenged by the Yersinia ruckeri (BCCM/LMG3279) strain. This test was carried out as described by (Gharaei et al. 2020b). The mortality percentage of fish in each group was measured after a 15-day resistance test period and the relative percentage of survival (RPS) was determined by the following formula: RPS=100-[(test mortality/control mortality) [100]

\subsection{Histopathological analysis}

On the last day of the trial, six randomly selected fish of each treated group were sampled. After anesthetized with $200 \mathrm{mg} \mathrm{l}^{-1}$ MS222 (Faggio et al. 2014), gill, liver, kidney, and intestine tissue samples with the size of $1 \times 1 \times 0.5 \mathrm{~cm}$ were preserved in $10 \%$ neutral buffered formalin for fixation. Afterward, the tissue preparation with the routine protocol (dehydration in ethanol, clearing in xylene, impregnation, and embedding in melted paraffin, sectioning at $5 \mu \mathrm{m}$ with a rotary microtome, and staining with hematoxylineosin standard staining method) was performed for the histopathological investigation by light microscopy (Mohammadi et al. 2020).

\subsection{Statistical analysis}

Normality and homogeneity of the data were tested before performed parametric tests. The data (means \pm $\mathrm{SE}$ ) from each group were subjected to one-way analysis of variance (ANOVA), and Tukey's post hoc test was used to rank the groups in SPSS (version 18) if significant differences $(p<0.05)$ were detected. The effects of dietary Cu-NPs and VC levels, as well as their interactions, were tested by two-way ANOVA. 


\section{Results}

Fluctuations of growth performance including WG, FCR, SGR, PER, and survival rate of juvenile common carp treated with different levels of dietary Cu-NPs or/and VC supplementation for 60 days are shown in Table 4. According to the experiments, WG, FCR, SGR, and PER were significantly affected only by Cu-NPs supplementation. In addition, the WG, SGR, and PER values were significantly higher $(p<0.05)$ in all treatment groups than in the control group (T1). The mortality rate in all treatment groups did not show any significant differences $(p<0.05)$. In addition, the FCR value was significantly $(p<0.05)$ decreased in all treatment groups compared with the control group (T1). Similarly, based on two-way ANOVA analysis, neither VC supplementation nor its interaction with Cu-NPs was effective on the FCR parameter and the other growth parameters (Table 4). The survival rate, which varied from $97.22 \%$ to $100 \%$, was not significantly different among the groups $(p>0.05)$.

As shown in Table 5, the lysozyme activity and $\mathrm{ACH} 50$ values were not significantly affected by the VC supplementation and the interaction of Cu-NPs Í VC. On the other hand, only Cu-NPs was the significant factor for the lysozyme activity and ACH50 levels of the fish fed on the trial diets when compared with the control group (T1). However, the fish fed on the T4 and T5 diets showed significantly higher $(p<0.05)$ lysozyme activity value than those fed on the $\mathrm{T} 1$ diet. But, the $\mathrm{ACH} 50$ value in all treatment groups was significantly $(p<0.05)$ more pronounced than that in the control group (T1). The highest level of ACH50 was recorded in the fish fed on the T5 diet (Table 5).

The variations in the activity of antioxidative enzymes (SOD, CAT, and GPX) are presented in Table 6. The two-way ANOVA test revealed that VC supplementation and Cu-NPs I VC were the significant factors $(\mathrm{p}<$ $0.05)$ for the SOD value, meanwhile the CAT and GPX levels were significantly $(p<0.05)$ affected only by Cu-NPs supplementation. According to the tests, the significant difference $(p<0.05)$ in the mean values of SOD gain among all treatment groups when compared with the control group (T1). In addition, the CAT and GPX contents were significantly increased in the fish fed on the T4 and T5 diets when compared with the control group (T1). Furthermore, the MDA value did not vary significantly $(p>0.05)$ with dietary treatments at the end of the trial.

After 60 days of treatment, there were significant differences in the hematological parameters as shown in Table 7. The $\mathrm{Hb}$ value was not significantly $(\mathrm{p}<0.05)$ affected by Cu-NPs supplementation and the interaction of Cu-NPs I VC, but the Hct and MCV values were significantly $(p<0.05)$ influenced only by the VC supplementation factor.

Cu-NPs had no effects on $\mathrm{Hb}, \mathrm{Hct}$, and MCV when the diet was not supplemented with VC. However, in the diets containing 250 and $500 \mathrm{mg} \mathrm{VC}$ and $2 \mathrm{mg}$ Cu-NPs supplementation, significant increases ( $p>0.05)$ were observed in blood $\mathrm{Hb}$, Hct, and MCV. Meanwhile, the RBC, WBC, and MCHC values did not significantly $(p>0.05)$ vary with dietary treatments at the end of the trial.

The relative mRNA expressions of TNF- $a$, IL-1ß, IL-10, SOD, CAT, and GPX genes in the intestinal after 60 days are shown in Table 8. The analysis of variance demonstrated that the interactive effects of dietary 
Cu-NPs and VC were significant on all target genes in the intestinal tissue. In the intestinal tissue of the fish fed on the T3, T4, and T5 diets, the expression of TNF-a, IL-1ß, IL-10, SOD, CAT, and GPX was significantly decreased versus the control group (Table 8).

Histopathological evaluation of the gills, kidneys, liver, and spleen revealed no damage in different tissues of fish treated with Cu-NPs and VCs (Figures 1-4).

The resistance of juvenile rainbow trout to the pathogen ( $Y$. ruckeri) after treatment with different diets is depicted in Figure 5. The trend of survival percentage indicated that Cu-NPs/CV supplementations significantly enhanced $(p<0.05)$ the fish resistance against $Y$. ruckeri when compared with the control. In addition, 15 days post-challenge with this bacterium, highest relative percentage of survival was recorded in fish fed on the T5 diet (75\%) and followed by those fed on the T4 diet (70\%).

\section{Discussion}

Recent studies have demonstrated that minerals and vitamins such as $\mathrm{Cu}$ and VC are required for normal cell functioning, improvement of growth performance, and physiological and immunological process of aquatic species (El Basuini et al. 2016; Dawood and Koshio 2016; Chen et al. 2015; Ai et al. 2006; Watanabe et al. 1997). Also, it has been reported that nanominerals such as Cu nanoparticles have novel features such as high surface activity, larger specific surface area, high catalytic efficiency, high surface active centers, and stronger adsorption capacity, making them more capable of crossing biological barriers so that they are rapidly absorbed by cells and exhibit higher bioavailability than mineral salts (Gharaei et al. 2020a; Izquierdo et al. 2016; Rather et al. 2011).

The present study showed that growth indices including WG, FCR, SGR, and PER were significantly affected by Cu-NPs and VC supplementations, which is in parallel with previous studies according to which dietary Cu and CV supplementations improved growth indices, immune response, and antioxidant status in several species of fish (El Basuini et al. 2016, Mohseni et al. 2014; Tang et al. 2013; Faramarzi 2012; Sabatini et al. 2009; Wang et al. 2009). The growth-promoting effects of Cu-NPs may be explained by the fact that optimal dietary copper induces growth by improving metabolism, activities of the brush border, and preventing lipid peroxidation and protein oxidation in the hepatopancreas and intestine (Tang et al. 2013). Although it has been demonstrated that growth performance is significantly increased in grass carp (Ctenopharyngodon idella), beluga (Huso huso), red sea bream (Pagrus major), and freshwater prawn (Macrobrachium rosenbergii) under the effect of dietary Cu supplementation (Tang et al. 2013; Mohseni et al. 2014; El Basuini et al. 2016; Muralisankar et al. 2015). However, unlike this study, Gatlin and Wilson (1986) and Lorentzen et al. (1998) reported no significant effect of Cu supplementation on WG and feed efficiency of channel catfish (Ictalurus punctatus) and Atlantic salmon (Salmo salar), respectively. Therefore, the severity of the response to copper supplementation and its different impact on growth performance may be attributed to species, age, Cu dosage, and Cu chemical forms.

Crustaceans and fish species are limitedly capable of VC synthesis, so adding it to the diet of farmed species is crucial for improving growth performance and maintaining normal physiological functions 
(Dawood and Kushio 2016; Chen et al. 2015). Improved growth performance through the nutrition of VC often appears as a result of the increased feed efficiency of the diet as proven by the previous studies on red seabream (P. major) (Dawood et al. 2016), Caspianrouch (Rutilus rutilus caspicus) (Roosta et al. 2014), common carp (C. carpio) (Liu et al. 2011), cobia (Rachycentron canadum) (Zhou et al. 2012), Oreochromis spilurus (Al-Armoudi et al. 1992), and Korean rockfish (Sebastes schegelii) (Kim and Kang 2015). In the present study, the growth performance reached a significantly higher level in the fish fed on the T5 diet (2 $\mathrm{mg} \mathrm{kg}^{-1}$ Cu-NPs mixed with $500 \mathrm{mg} \mathrm{kg}^{-1} \mathrm{VC}$ ) compared with the control group. Adel and Khara (2016) presented that the highest WG and SGR and lowest FCR in rainbow trout fingerlings were observed in those fed on $250 \mathrm{mg} \mathrm{kg}^{-1} \mathrm{VC}$. Yousefi et al. (2013) evidenced that the growth performance of Barbus sharpeyi was improved by VC supplementation. Similarly, Faramarzi (2012) indicated that the growth performance of common carp was increased in the fish fed on dietary VC supplementation at a rate of $800-2000 \mathrm{mg}$ $\mathrm{kg}^{-1}$ diet. Unlike this study, it was reported that dietary VC supplementation did not influence the growth performance in large yellow croaker (Pseudosciaena crocea) juveniles (Ai et al. 2006). However, our results in this study revealed that Cu-NPs combined with VC have a synergism effect on the growth indices and the physiological status of rainbow trout.

Lysozyme and ACH50 widely participate as humoral components in the innate defense system, so they are important for fish protection against diseases (Kaya et al. 2016). The antibacterial activity of the complement system, reported in various fish, has been suggested as one of the most important mechanisms of bacterial killing and clearing in fish, which can be activated by various immune stimuli (Srivastava \& Pandey 2015). One of the triggers of complement activation is cytokines, some of which are effective in regulating proteins involved in iron metabolism, such as ceruloplasmin (Di Bella et al. 2017). In our study, lysozyme activity enzyme and ACH50 value were enhanced significantly $(p<0.05)$ in fish fed on the Cu-NPs and/or CV supplemented diet. This incremental fluctuation may be due to the immune suppressive effects of Cu-NPs (Kaya et al. 2016). This result coincides with the investigation of El Basuini et al. (2016) and Mohseni et al. (2014) who reported increasing lysozyme level in P. major and $H$. huso fed on dietary Cu-NPs and inorganic copper supplementations, respectively. In addition, Gharaei et al. (2020a) indicated that the lysozyme and $\mathrm{ACH} 50$ values were increased in $\mathrm{H}$. huso fed on the dietary Chitosan- $\mathrm{Zn}$ NPs supplemented diet. Unfortunately, there is a lack of knowledge on the effect of nanoparticles on the ACH50 level in fish. However, it has been demonstrated that VC is a strong inducer of the immune system, especially non-specific immunity as it results in enhanced lysozyme activity level reported in various fish species including P. major (El Basuini et al. 2016); O. mykiss (Adel and Khara 2016); Pseudosciaena crocea (Ai et al. 2004, 2006); Takifugu rubripes (Eo and Lee 2008); Scophthalmus maximus (Lin and Shiau 2005), Pangasianodon gigas (Pimpimol et al. 2012). Qinghui et al. (2004) observed increased fish lysozyme and $\mathrm{ACH} 50$ values when the dietary VC supplementation was enhanced up to $489.0 \mathrm{mg} \mathrm{kg}^{-1}$. Similarly, Chen et al. (2003) demonstrated that the ACH50 level in golden shiner (Notemigonus crysoleucas) was increased under the effects of dietary VC supplementation.

The antioxidant defense system is highly correlated with the health and safety of fish, and its major enzymes (SOD, CAT, GPX, and MDA) decompose reactive oxygen species (ROS) into a less reactive form (Sheikh Asadi et al. 2018; Dekani et al. 2018). The role of SOD is to stimulate the oxidation and reduction 
of superoxide anions to hydrogen peroxides, which are then used as a substrate by the CAT and GPX enzymes (Saffari et al. 2016). As shown in Table 5, maximum activities of the SOD, CAT, and GPX enzyme are observed in the fish fed on the T5 ( $2 \mathrm{mg} \mathrm{kg}^{-1}$ Cu-NPs mixed with $\left.500 \mathrm{mg} \mathrm{kg}^{-1} \mathrm{VC}\right)$ diet compared with the control group. Previous studies have shown that Cu-containing diet, Cu/Zn-SOD enzyme activities in hepatocyte of rainbow trout (Oncorhynchus mykiss) (Osredkar and Sustar, 2011; Trenzado et al. 2009) and grass carp (Ctenopharyngodon idella) (Tang et al. 2013) and GPX increases in the plasma of goldfish (Carassius auratus gibelio) (Shao et al. 2010). In fact, copper is positively associated with the antioxidant defense system (Fang et al. 2013) and the effect of dietary copper on stopping oxidative damage may be related to the reaction with ROS such as anion superoxides and hydroxyl radicals (Tang et al. 2013). On the other hand, ceruloplasmin is a Cu-containing protein whose activity increases with appropriate levels of dietary $\mathrm{Cu}$ (Shaiu and Ning 2003). This Cu-containing protein is capable of stopping superoxide radical production (Valko et al. 2007) and hydroxyl radical formation (Zhang et al. 2013). One of the major antioxidant additives in the fish diet and food industry is VC, which alleviates oxidative stress (Dawood et al. 2016; Geo et al. 2013). VC plays an important role in scavenging free radicals (ROS and reactive nitrogen species) by acting as an early electron donor and reducing the agent (Dawood et al. 2016). Many previous studies have stated that dietary VC supplementation increases the SOD, CAT, and GPX activities in yellow catfish (Pelteobarus fulvidaco) (Liang et al. 2015), Siberian sturgeon (Acipenser baerii) (Xie et al. 2006), and black carp (Mylopharyngodon piceus) (Hu et al. 2013). Therefore, the results suggested that dietary Cu-NPs + VC supplementation are probably able to increase the antioxidant level and they have a synergistic interactive effect on inducing the antioxidant system. Our results showed no significant variations in the MDA value in all treatments. On the contrary, Jankowski et al. (2020) reported a reduction of MDA concentration under the effects of various forms of $\mathrm{Cu}$ (mineral and nanoparticle) in turkeys.

Hematological assessments can provide an indication of the physiological status of fish (Behera et al. 2013). In the present study, the Hb, Hct, and MCV values were increased more significantly in the fish fed on the T5 diet ( $2 \mathrm{mg} \mathrm{kg}^{-1}$ Cu-NPs mixed with $500 \mathrm{mg} \mathrm{kg}^{-1} \mathrm{VC}$ ) than the control fish, suggesting the positive effect of $\mathrm{Cu}-\mathrm{NPs}+\mathrm{VC}$ on physiological responses. The lower values of these hematological parameters in the control group indicate the necessity of adding $\mathrm{Cu}$ and $\mathrm{VC}$ to the diet to improve blood counts. The measured levels of blood variables in the normal range are for trout health, which confirms the effects of non-toxic Cu-NPs used under the present experimental conditions. It was confirmed that increased $\mathrm{Hb}$ indicates a stress response or increased hematopoiesis (Clauss et al. 2008). While the fish fed on Cu-NPs/VC were healthier than the control group, which was determined by the level of antioxidant, safety, and survival rates in the bacterial stress test. Thus, an increase in RBC, $\mathrm{Hct}$, and $\mathrm{Hb}$ associated with hematopoiesis increased or decreased hemolysis (Hosseini et al. 2018). This may be due to the role of $\mathrm{Cu}$ as a combination of many enzymes and glycoproteins that aid in the synthesis of hemoglobin (Nordberg et al. 2015; Dawood et al. 2020). Ceruloplasmin (a liver-derived protein) is required to release iron and transfer it from cells and tissues to plasma. There are several copper molecules in the structure of this protein, and its synthesis in the liver requires the presence of copper. In fact, copper deficiency impairs the ability of iron absorption or release from tissues for hemoglobin synthesis (Haver and Hardy 2008). The same results were recorded by Adel and Khara (2016) and Zhou et al. (2012) for pirarucu (Arapaima gas) and cobia ( $R$. canadum), respectively. 
To investigate the effects of Cu-NPs and VC on inflammatory and antioxidant responses, we measured the expression of several gene biomarkers including three pro-inflammatory cytokines (TNF-a, IL-10, and IL-1ß) and three antioxidant systems (CAT, SOD, and GPX). The results of the present study showed that the expression levels of TNF-a, IL-10, and IL-1ß genes were decreased in the intestine of the fish in the T3, T4, and T5 treatment groups. TNF- $a$ (tumor necrosis factor) is known as a multifunctional cytokine that plays a key role in cell-mediated inflammatory immunity responses (Lykouras et al. 2008; Mocellin et al. 2015). IL-1ß acts as a mediator of the inflammatory response and helps reduce inflammatory pain sensitivity in various cellular activities, including cell proliferation and apoptosis by inducing cyclooxygenase-2 (PTGS2 /COK2) in the central nervous system. TNF- $a$ and IL-1ß are considered important indicators of phagocytic activity and they are the first cytokines produced in the early stages of inflammation in fish (Skadberg et al. 2015). IL-10 is known as a cytokine synthesis inhibitory factor that minimizes damage to target cells by suppressing the transcription of pro-inflammatory cytokine (Shafiei-Jahani et al. 2020). The significant reduction in the expression of pro-inflammatory cytokine genes in fish fed on the diets containing $\mathrm{Cu}$ NPs/VC supplements can be interpreted as their significantly down-regulated synergistic effect on the immune response, which was also dose-dependent. IL-10 has also been reported to be capable of degrading pro-inflammatory cytokine mRNA, reducing TNF-a receptor expression, and regulating macrophage-derived TNF-a and IL-1 secretion (Opal et al. 1998; Opal and DePalo 2000). Suska et al. (2003) reported that cellular $\mathrm{Cu}$ sites induce the secretion of TNF- $\mathrm{a}$ and IL-1ß by inflammatory cells ex vivo and in vivo. On the other hand, TNF-a has been shown to increase phagocytosis of neutrophils under apoptosis. Thus, Cu-NPs may reduce the production of pro-inflammatory cytokine because $\mathrm{Cu}$ ion is closely related to RNA and DNA. Antioxidant vitamins, including VC, can increase immune function by increasing the proliferation of lymphocytes and macrophages (Jang et al. 2014). Changes in gene expression reported in this study suggest a low inflammatory potential of the Cu-NPs / VCs tested. In this regard and consistent with our results, Yun et al. (2012) and Jang et al. (2014) reported that dietary supplemental VC significantly reduced TNF-a, IL-1ß, and IL-6 mRNA levels in mice and broiler chick, respectively.

Despite the various benefits of copper nanoparticles in aquatic organisms, their toxic effects have also been reported in some cases. In Epinephelus coioides, adverse effects on gut, gill, and liver (Wang et al. 2015), Cyprinus carpio caused a sharp decrease in alkaline phosphatase and increased T4 and free T4 in blood plasma (Hoseini et al. 2016), Oncorhynchus mykiss reduced hematocrit percentage and the amount of potassium and sodium in the blood plasma (Shaw et al. 2012). Nowadays, the interaction between transition metals, e.g., $\mathrm{Cu}$, with VC is well known (Akbıyık et al. 2012) as the rate of VC oxidation stability increases with the fixed concentration of $\mathrm{Cu}$ and prevents catalytic oxidation of $\mathrm{VC}$ in the presence of a stable Cu complex.

Various studies have shown that dietary VC can produce antioxidants (Biller et al. 2018). VC bonds to ROS in the body and retrieves free radicals through $\mathrm{H}^{+}$donation. $\mathrm{VC}$ has also been shown to act as a reducing agent, primarily by reducing the transport of metals such as $\mathrm{Cu}$ and Fe ions, which react with $\mathrm{H}_{2} \mathrm{O}_{2}$ to form hydroxyl radicals (Babior 1997). 
Despite reports of inducing increased expression of the SOD, CAT, and GPX genes due to the toxicity of CuNPs in aquatic organisms (Ramya et al. 2016; Muralisankar et al. 2019; Dawood et al. 2020). The results of this experiment suggested that the Cu-NP level of $2 \mathrm{mg} \mathrm{kg}^{-1}$ had no adverse effect on fish and, when applied with VC, had the greatest effect on ROS production. SOD and CAT are related to stress management ( $\mathrm{Li}$ et al. 2010) and are used as important indicators in the early detection of oxidative pollution. Decreased expression of the SOD, CAT, and GPX genes in fish exposed to Cu-NPs/VC could indicate oxidant eradication. The results of Nile tilapia (Oreochromis niloticus) exposed to ZnO-NPs and vitamins $C$ and E (Abdelazim et al. 2018), O. niloticus exposed to Ag-NPs (Afifi et al. 2013), and Carassius auratus exposed to a mixture of Cu-NPs and ZnO-NPs and cerium oxide-NPs and pure NP (Xia et al. 2013) are in agreement with our findings. It is confirm that $\mathrm{VC}$ can destroy the superoxide anion by forming radical semidehydra ascorbate (Abdelazim et al. 2018). The results of our experiment showed significant neutralization in the antioxidant system so that the fish fed on a mixture of Cu-NPs and VC exhibited the lowest expression level of the SOD, CAT, and GPX genes. This ability of VCs to combat possible oxidative damage was caused by exposure to Cu-NPs. Othman et al. (2017) explained that they used VC to prepare ligands for cerium oxide nanoparticles as a tool to facilitate the detection of NP in tissues because they suggested that VC could bind tightly to NPs and showed its performance. It has also been reported that the presence of NPs themselves can increase the VC activity (Astete et al. 2011).

The maximum resistance to $Y$. ruckeri and survival rate in this study were recorded in the fish fed on the T5 diet. Many previous studies have shown that various dietary additives have increased the survival rate and resistance to the pathogen in rainbow trout (Gharaei et al. 2020b; Yilmaz et al. 2018; Aghamirkarimi et al. 2017). The significant enhancement in survival rate in this study may be related to the induction of nonspecific immune defenses and antioxidant system by synergistic interaction of Cu-NPs and VC.

In the present study, histopathological alterations were not observed in gill, intestine, liver, and kidney tissues affected by Cu-NPs and Cu-NPs + VC. According to the previous studies, the gill, liver, and kidney are the most sensitive organs to Cu-NP exposure and respond by showing various degrees of necrosis and tissue damage (Ostaszewska et al. 2018). Gills are an important organ with several functions like respiratory osmoregulation and respiratory gas exchange, acid-base balance, and excretion of metabolites. Thus, they are the primary target for a high concentration of Cu-NPs (Ostaszewska et al. 2018).

The intestine is the site of absorption of a huge portion of the nutrients and non-nutrients digested. It has been shown that Cu-NPs are well oxidized to ionic forms in acidic environments and have high adsorption capacity (Pirarat et al. 2011). On the other hand, the height of intestinal villi is an important indicator of the efficiency of digestion and absorption in the gut (Ringoe et al. 2003). Rathore et al. (2019) has reported that dietary VC increases the height of villi in the gut of tilapia (Oreochromis niloticus). The combination of Cu-NPs and vitamin $\mathrm{C}$ is likely to increase the efficiency of nutrient absorption in the gut by providing a larger surface area as well as an acidic environment of the gut, which strengthens the immune system against the pathogens through the viscous mucin layers that cover the receptors for infectious agents (present on the intestinal mucosa) (Johari et al. 2015). 


\section{Conclusion}

In conclusion, our study identified some changes in growth, blood, biochemical, immune, and histopathology parameters of rainbow trout juveniles under the influence of dietary Cu-NPs and/or CV supplementations. Based on the data obtained, a diet containing $2 \mathrm{mg}$ Cu-NPs combined with $500 \mathrm{mg}$ VC per kg food can improve the growth indices including WG. FCR, SGR, PER, and blood indices including $\mathrm{Hb}$, Hct, MCV, and biochemical and immunological indices including SOD, CAT, GPX, ACH50, and lysozyme. It appears that the synergistic effect of Cu-NPs and VC improves feed utilization, metabolism efficiency, and intestine tissue structure and enhances the antioxidant capacity and immune system in rainbow trout. However, additional studies are required to evaluate the other effects of these supplements on the immune responses and blood parameter variations and why some of the results differ from those of the previous studies. This research indicated that a combination of Cu-NPs and CV could be used in the rainbow diet as a growth promoter as it can improve the physiological conditions and resistance against pathogens.

\section{Declarations}

\section{- Acknowledgment}

We thank Dr. Khosravanizadeh for his time and energy and all staff of Hamoon International Wetland Research Institute for the financial support and cooperation. The research project was funded by the University of Zabol (Grant cod: UOZ-GR-9618-94).

\section{- Funding}

The research project was funded by the University of Zabol (Grant cod: UOZ-GR-9618-94).

\section{-Conflicts of interest}

The authors declare that they have no competing interests.

\section{-Ethics approval}

All procedures were carried out in accordance with the Animal Care and Use Committee guidelines at the Faculty of Sciences of the University of Zabol.

\section{-Consent to participate (include appropriate statements)}

The authors agree to collaborate and publish this article. 


\section{-Consent for publication (include appropriate statements)}

We will transfer the copyright of the article to editorial office for publishing.

\section{-Availability of data and material/ Data availability}

The datasets generated during and/or analyzed during the current study are available from the corresponding author on reasonable request.

\section{-Code availability}

Not applicable

\section{-Authors' contributions (include all authors)}

Delavari M.: MSc student; these data are coming from his thesis.

Gharaei A.: Asssociate professor in the Deptartment of Fisheries and the main supervisor for the student. He provided all the scientific suggestions and grants.

Mirdar Harijani J.: He is the second supervisor and provided scientific suggestions.

Davari A.: She was the advisor for the work and provided scientific comments.

Rastiannasab A.: He was the advisor for the scientific group.

\section{References}

1. Abdelazim AM, Saadeldin IM, Swelum AA, Afifi M, Alkaladi A (2018) Oxidative Stress in the Muscles of the Fish Nile Tilapia Caused by Zinc Oxide Nanoparticles and Its Modulation by Vitamins $C$ and E. Oxid Med Cell Longev 12-19. https://doi.org/10.1155/2018/6926712

2. Adel A, Khara $H$ (2016) The effects of different dietary vitamin $C$ and iron levels on the growth, hematological and immunological parameters of rainbow trout Oncorhynchus mykiss fingerlings. Iranian J Fish Sci 15:886-897.

3. Afifi M, Saddick S, Abu Zinada OA (2013) Toxicity of silver nanoparticles on the brain of Oreochromis niloticus and Tilapia zillii. Saudi J Biol Sci 26:742-749. https://doi.org/10.1016/j.sjbs.2016.06.008

4. Aghamirkarimi S, Mashinchian Moradi A, Sharifpour I, Jamili S, Ghavam Mostafavi P (2017) Sublethal effects of copper nanoparticles on the histology of gill, liver and kidney of the Caspian roach, Rutilus rutilus caspicus. Global J Environ Sci Manage 3:323-332.

https://doi.org/10.22034/gjesm.2017.03.03.009 
5. Ai QH, Mai KS, Tan BP et al (2006) Effects of dietary vitamin C on survival, growth, and immunity of large yellow croaker, Pseudosciaena crocea. Aquacul 261:327-336.

https://doi.org/10.1016/j.aquaculture.2006.07.027

6. Akbıyık T, Sönmezoğlu İ, Güçlü K, Tor İ, Apak R (2012) Protection of ascorbic acid from copper (II)catalyzed oxidative degradation in the presence of fruit acids: Citric, oxalic, tartaric, malic, malonic, and fumaric acids. Int J Food Prop 15:398-411.

7. Al-Armoudi MM, El-Nakkadi AMN, El-Nounan BM (1992) Evaluation of optimum dietary requirement of vitamin $\mathrm{C}$ for the growth of Oreochromis spilurus fingerlings in water from the Red Sea. Aquacul 105:165-173. https://doi.org/10.1016/0044-8486(92)90128-8

8. Astete CE, Dolliver D, Whaley M, Khachatryan L, Sabliov CM (2011) Antioxidant poly(lactic-co-glycolic) acid nanoparticles made with a-tocopherol-ascorbic acid surfactant. ACS Nano 5:9313-9325. https://doi.org/10.1021/nn102845t

9. Atencio L, Moreno I, Jos A (2009) Effects of dietary selenium on the oxidative stress and pathological changes in tilapia (Oreochromis niloticus) exposed to a microcystin-producing cyanobacterial water bloom. Toxicol 53:269-282. https://doi.org/10.1016/j.toxicon.2008.11.011

10. Babior BM (1997) Superoxide: a two-edged sword. Braz J Med Biol Res 30:141-155. https://doi.org/10.1590/S0100-879X1997000200001

11. Behera T, Swain P, Rangacharulu PV, Samanta M (2013) Nano-Fe as feed additive improves the hematological and immunological parameters of fish, Labeo rohita $\mathrm{H}$. Appl Nanosci 4:687-694. https://doi.org/10.1007/s13204-013-0251-8

12. Biller JD, Takahashi LS (2018) Oxidative stress and fish immune system: phagocytosis and leukocyte respiratory burst activity. An Acad Bras Cienc 90:3403-3414. https://doi.org/10.1590/00013765201820170730

13. Chahardeh Baladehi E, Hedayati SAA, Kolangimiandare H, Bagheri T (2017) The hematological improvement of rainbow trout (Oncorhynchus mykiss) during dietary supplementation with vitamin $\mathrm{C}$ after exposure to zinc nano-particles. Iranian J Fish Sci 16:162-169.

14. Chen R, Lochmann R, Goodwin A (2003) Alternative Complement Activity and Resistance to Heat Stress in Golden Shiners (Notemigonus crysoleucas) are increased by Dietary Vitamin C Levels in Excess of Requirements for Prevention of Deficiency Signs. J Nutr 133:2281-2286. https://doi.org/10.1093/jn/133.7.2281

15. Chen YJ, Yuan RM, Liu YJ et al (2015) Dietary vitamin C requirement and its effects on tissue antioxidant capacity of juvenile largemouth bass, Micropterus salmoides. Aquacul 435:431-436. https://doi.org/10.1016/j.aquaculture.2014.10.013

16. Clauss TM, Dove AD, Arnold JE (2008) Hematologic disorders of fish. Vet Clin North Am Exot Anim Pract 11:445-462. https://doi.org/10.1016/j.cvex.2008.03.007

17. Combs GF (2008) The Vitamines, Fundamental Aspects in Nutrition and Health, $3^{\text {rd }}$ edn, Elsevier Academic Press, Burlington. https://doi.org/10.1080/07315724.2000.10718917 
18. Davis DA, Lawrence AL, Gatlin DM III (1993) Evaluation of the dietary zinc requirement of Penaeus vannamei and effects of phytic acid on zinc and phosphorus bioavailability. J World Aquac Soc 24:40-47. https://doi.org/10.1111/j.1749-7345.1993.tb00148.x.

19. Dawood MAO, Eweedah NM, Moustafa EM et al (2020) Copper Nanoparticles Mitigate the Growth, Immunity, and Oxidation Resistance in Common Carp (Cyprinus carpio). Biol Trace Elem Res 198:283-292. https://doi.org/10.1007/s12011-020-02068-0

20. Dawood MAO, Koshio S (2016) Vitamin C supplementation to optimize growth, health and stress resistance in aquatic animals. Rev Aquacult 10:334-350. https://doi.org/10.1111/raq.12163.

21. Dekani L, Johari SA, Salarijoo H (2018) Comparative toxicity of organic, inorganic and nanoparticulate zinc following dietary exposure to common carp (Cyprinus carpio). Sci Total Environ 656:1191-1198. https://doi.org/10.1016/j.scitotenv.2018.11.474

22. Di Bella LM, Alampi R, Biundo F, Toscano G, Felice MR (2017) Copper chelation and interleukin-6 proinflammatory cytokine effects on expression of different proteins involved in iron metabolism in HepG2 cell line. BMC Biochem 18:1-11. https://doi.org/ 10.1186/s12858-017-0076-2

23. El Basuini MF, El-Hais AM, Dawood MA et al (2016) Effect of different levels of dietary copper nanoparticles and copper sulfate on growth performance, blood biochemical profiles, antioxidant status and immune response of red sea bream (Pagrus major). Aquacul 455:32-40. https://doi.org/10.1016/j.aquaculture.2016.01.007

24. Ellis AE (1990) Lysozyme assays. Tech. Fish Immunol 1101-103.

25. Eo J, Lee K (2008) Effect of dietary ascorbic acid on growth and nonspecific immune responses of tiger puffer, Takifugu rubripes. Fish Shellfish Immun 25:611-616. https://doi.org/10.1016/j.fsi.2008.08.009

26. Faggio C, Fedele G, Arfuso F, Panzera M, Fazio F (2014) Haematological and Biochemical Response of Mugil cephalus after Acclimation to Captivity. Cah Biol Mar 55:31-36.

27. Fang KM, Cheng FC, Huang YL et al (2013) Trace element, antioxidant activity, and lipid peroxidation levels in brain cortex of gerbils after cerebral ischemic injury. Biol Trace Elem Res 152:66-74. https://doi.org/10.1007/s12011-012-9596-1

28. Faramarzi M (2012) Effect of dietary vitamin C on growth and feeding parameters, carcass composition and survival rate of Common Carp (Cyprinus carpio). Glob Vet 8:507-510.

29. Fracalossi DM, Allen ME, Yuyama LK, Oftedal OT (2001) Ascorbic acid biosynthesis in amazonian fishes. Aquacul 192:321-332. https://doi.org/10.1016/S0044-8486(00)00455-5

30. Gao J, Koshio S, Ishikawa M, Yokoyama S, Mamauag REP (2014) Interactive effects of vitamin C and E supplementation on growth performance, fatty acid composition and reduction of oxidative stress in juvenile Japanese flounder Paralichthys olivaceus fed dietary oxidized fish oil. Aquacul 422:84-90. https://doi.org/10.1016/j.aquaculture.2013.11.031

31. Gatlin DM, Wilson RP (1986) Dietary copper requirement of fingerling channel catfish. Aquacul 54:277285. https://doi.org/10.1016/0044-8486(86)90272-3 
32. Gharaei A, Ghafari M, Keyvanshokooh S, Akrami R (2010) Changes in Metabolic Enzyme, Cortisol and Glucose of Beluga (Huso huso) exposed to Dietary Methylmercury. Fish Physiol Biochem 37:485-493. https://doi.org/10.1007/s10695-010-9450-3

33. Gharaei A, Ghaffari M, Keyvanshokooh S, Akrami R (2011) Changes in metabolic enzymes, cortisol and glucose concentrations of Beluga (Huso huso) exposed to dietary methylmercury. Fish Physiol Biochem 37:485-493. https://doi.org/10.1007/s10695-010-9450-3

34. Gharaei A, Khajeh M, khosravanizadeh A, Mirdar Harijani J, Fadaei R (2020a) Fluctuation of biochemical, immunological and antioxidant biomarkers in blood of beluga (Huso huso) under effect of dietary ZnO and Chitosan-ZnO NPs. Fish Physiol Biochem 46:547-561.

https://doi.org/10.1007/s10695-019-00726-2

35. Gharaei A, Shafiei M, Mirdar Harijani J, Hassanein P, Arshadi A (2020b) Immune Responses and Haematological Parameters Changes of Rainbow Trout (Oncorhynchus mykiss) under Effects of Dietary Administration of Sumac (Rhus coriaria). J Agr Sci Tech 22:173-186. https://doi.org/10.1016/j.fsi.2017.08.022

36. Grosso G, Bei R, Mistretta A et al (2013) Effects of vitamin C on health: a review of evidence. Front Biosci Landmark 18:1017-29. https://doi.org/10.2741/4160

37. Haver JE, Hardy RW (2002) Fish Nutrition 3 edition. Academic Press, 260-308.

38. Hoseini SM, Hedayati A, Mirghaed AT, Ghelichpour M (2016) Toxic effects of copper sulfate and copper nanoparticles on minerals, enzymes, thyroid hormones and protein fractions of plasma and histopathology in common carp Cyprinus carpio. Exp Toxicol Pathol 68:493-503. https://doi.org/10.1016/j.aquatox.2012.02.032

39. Hoseini SM, Mirghaed AT, Iri Y, Ghelichpour M (2018) Effects of dietary cineole administration on growth performance, hematological and biochemical parameters of rainbow trout (Oncorhynchus mykiss). Aquacult 495:766-772. https://doi.org/10.1016/j.aquaculture.2018.06.073

40. Hoseini SM, Yousefi M, Taheri Mirghaed A et al (2020) Effects of rearing density and dietary tryptophan supplementation on intestinal immune and antioxidant responses in rainbow trout (Oncorhynchus mykiss). Aquacul 528:735537. https://doi.org/10.1016/j.aquaculture.2020.735537

41. Hu Y, Huang Y, Wen H (2013) Effect of vitamin C on growth, immunity and anti-ammonia-nitrate stress ability in juvenile black carp (Mylopharyngodon piceusasiaticus). Shuichan Xuebao 37:565-573 (In Chinese, with English abstract)

42. Izquierdo MS, Ghrab W, Roo J et al (2016) Organic, inorganic and nanoparticles of Se, Zn and Mn in early weaning diets for gilthead seabream, Sparus aurata; Linnaeus, 1758. Aquac Res 48:2852-2867. https://doi.org/10.1111/are.13119

43. Jafarinejad R, Gharaei A, Mirdar Harijani J (2020) Dietary ginger improve growth performance, blood parameters, antioxidant capacity and gene expression in Cyprinus carpio. Iranian J Fish Sci 19:12371252. https://doi.org/10.22092/ijfs.2018.119876

44. Jang IS, Ko YH, Moon YS, Sohn SH (2014) Effects of vitamin C or E on the pro-inflammatory cytokines, heat shock protein 70 and antioxidant status in broiler chicks under summer conditions. Asian- 
australas. J Anim Sci 27749. https://doi.org/10.5713/ajas.2013.13852

45. Jankowski J, Otowski K, Kozłowski K et al (2020) Effect of different levels of copper nanoparticles and copper sulfate on morphometric indices, antioxidant status and mineral digestibility in the small intestine of turkeys. Ann Anim Sci https://doi.org/ 10.2478/aoas-2020-0013

46. Johari SA, Kalbassi MR, Yu IJ, Lee JH (2015) Chronic effect of waterborne silver nanoparticles on rainbow trout (Oncorhynchus mykiss): histopathology and bioaccumulation. Comp Clin Path 24:9951007. https://doi.org/10.1007/s00580-014-2019-2

47. Kaya H, Aydın F, Gürkan M et al (2016) A comparative toxicity study between small and large size zinc oxide nanoparticles in tilapia (Oreochromis niloticus): organ pathologies, osmoregulatory responses and immunological parameters. Chemosphere 144:571-582.

https://doi.org/10.1016/j.chemosphere.2015.09.024

48. Kim JH, Kang JC (2015) Influence of dietary ascorbic acid on the immune responses of juvenile Korean rock fish Sebastes schlegelii. J Aquat Anim Health 27:178-184.

https://doi.org/10.1080/08997659.2015.1050128

49. Lee MH, Shiau SY (2002) Dietary copper requirement of juvenile grass shrimp, Penaeus monodon, and effects on non-specific immune responses. Fish Shellfish Immun 13:259-270. https://doi.org/ 10.1006/fsim.2001.0401

50. Li ZH, Velisek J, Zlabek V et al (2010) Hepatic antioxidant status and hematological parameters in rainbow trout, Oncorhynchus mykiss, after chronic exposure to carbamazepine. Chem Biol Interact 183:98-104.https://doi.org/10.1016/j.cbi.2009.09.009

51. Liang XP, Li Y, Hou YM, Qiu H, Zhou QC (2017) Effect of dietary vitamin C on the growth performance, antioxidant ability and innate immunity of juvenile yellow catfish (Pelteobagrus fulvidraco Richardson). Aquacal Res 48:149-160. https://doi.org/10.1111/are.12869

52. Lin MF, Shiau SY (2005) Dietary L-ascorbic acid affects growth, nonspecific immune responses and disease resistance in juvenile grouper, Epinephelus malabaricus. Aquacul 244:215-221. https://doi.org/10.1016/j.aquaculture.2004.10.026

53. Lin YH, Shie YY, Shiau SY (2008) Dietary copper requirements of juvenile grouper, Epinephelus malabaricus. Aquacul 274:161-165. https://doi.org/10.1016/j.aquaculture.2010.10.004Get

54. Liu Y, Chi L, Feng L et al (2011) Effects of graded levels of dietary vitamin C on the growth, digestivecapacity and intestinal microflora of juvenile Jian carp (Cyprinus carpio). Aquac Res 42:534548. https://doi.org/10.1111/j.1365-2109.2010.02649.x

55. Lorentzen M, Maage A, Julshamn K (1998) Supplementing copper to a fish meal based diet fed to Atlantic salmon parr affects liver copper and selenium concentrations. Aquac Nutr 4:67-77. https://doi.org/10.1046/j.1365-2095.1998.00046.x

56. Lykouras D, Sampsonas F, Kaparianos A, Karkoulias K, Spiropoulos K (2008) Role and pharmacogenomics of TNF-alpha in asthma. Mini-Rev Med Chem 8:934-942. https://doi.org/10.2174/138955708785132828 
57. Mocellin S, Verdi D, Pooley KA, Nitti D (2015) Genetic variation and gastric cancer risk: a field synopsis and meta-analysis. Gut 64:1209-1219. https://doi.org/10.1136/gutjnl-2015-309168

58. Mohammadi M, Imania A, Farhangi M, Gharaei A, Hafeziehd M (2020) Replacement of fishmeal with processed canola meal in diets for juvenile Nile tilapia (Oreochromis niloticus): Growth performance, mucosal innate immunity, hepatic oxidative status, liver and intestine histology. Aquacult 518:734824. https://doi.org/10.1016/j.aquaculture.2019.734824

59. Mohseni M, Pourkazemi M, Baim SC (2014) Effects of dietary inorganic copper on growth performance and immune response of juvenile beluga, Huso huso. Aquacul Nutr 20:547-556. https://doi.org/10.1111/anu.12107

60. Muralisankar T, Bhavan PS, Radhakrishnan S et al (2014) Dietary supplementation of zinc nanoparticles and its influence on biology, physiology and immune responses of the freshwater prawn, Macrobrachium rosenbergii. Biol Trace Elem Res 160:56-66. https://doi.org/10.1007/s12011014-0026-4

61. Muralisankar T, Bhavan PS, Radhakrishnan S, Seenivasan C, Srinivasan V (2016) The effect of copper nanoparticles supplementation on freshwater prawn Macrobrachium rosenbergii post larvae. J Trace Elem Med Biol 34:39-49. https://doi.org/10.1016/j.jtemb.2015.12.003

62. Nootash S, Sheikhzadeh N, Baradaran B et al (2013) Green tea (Camellia sinensis) administration induces expression of immune relevant genes and biochemical parameters in rainbow trout (Oncorhynchus mykiss). Fish Shellfish Immunol 35:1916-1923. https://doi.org/ 10.1016/j.fsi.2013.09.030

63. Nordberg GF, Fowler BA, Nordberg M (2015) Toxicology of metals: overview, definitions, concepts, and trends. In: Handbook on the Toxicology of Metals. Elsevier. https://doi.org/10.1016/C2011-0-07884-5

64. Opal SM, DePalo VA (2000) Anti-inflammatory cytokines. Chest 117:1162-72. https://doi.org/10.1378/chest.117.4.1162

65. Opal SM, Wherry JC, Grint P (1998) Interleukin-10: potential benefits and possible risks in clinical infectious diseases. Clin Infect Dis 271:497-507. https://doi.org/10.1086/515032

66. Osredkar J, Sustar N (2011) Copper and zinc, biological role and significance of copper/zinc imbalance. Clin Toxicol 3:2161-0495. https://doi.org/10.4172/2161-0495.S3-001

67. Ostaszewska T, Śliwiński J, Kamaszewski M, Sysa P, Chojnacki M (2018) Cytotoxicity of silver and copper nanoparticles on rainbow trout (Oncorhynchus mykiss) hepatocytes. Environ Sci Pollut Res 25:908-915. https://doi.org/10.1007/s11356-017-0494-0

68. Othman A, Andreescu D, Karunaratne DP, Babu SV, Andreescu S (2017) Functional paper-based platform for rapid capture and detection of $\mathrm{CeO}_{2}$ nanoparticles. ACS Appl Mater 9:12893-12905. https://doi.org/10.1021/acsami.7b02823

69. Pekiner B, Nebioglu S (1994) Effect of vitamin C on copper and iron status in men and guinea pigs. J Nutr Sci Vitaminol 40:401-410. https://doi.org/10.3177/jnsv.40.401

70. Pimpimol T, Phoonsamran K, Chitmanat C (2012) Effect of dietary vitamin C supplementation on the blood parameters of Mekong giant cat fish (Pangasianodongigas). Int J Agric Biol 14:256-260. 
https://doi.org/10.1016/S0044-8486(01)00793-1

71. Pirarat N, Pinpimai K, Endo M et al (2011) Modulation of intestinal morphologyand immunity in Nile tilapia (Oreochromis niloticus) by Lactobacillus rhamnosus. Res Vet Sci 91:92-97. https://doi.org/10.1016/j.rvsc.2011.02.014

72. Qinghui A, Mai K, Zhang C et al (2004) Effects of dietary vitamin C on growth and immune response of Japanese sea bass, Lateo labrax japonicas. Aquacul 242:489-500. https://doi.org/10.1016/j.aquaculture.2004.08.016

73. Ramya E, Rao MV, Rao DN (2019) Nonlinear optical properties of Ag-enriched ZnO nanostructures. J Nonlinear Opt Phys Mater 281950027. https://doi.org/10.1142/S0218863519500279

74. Rather MA, Sharma R, Aklakur M et al (2011) Nanotechnology: A Novel Tool for Aquaculture and Fisheries Development. A Prospective Mini-Review. Fish Aquacul J 16:1-5. https://doi.org/10.4172/2150-3508.1000016

75. Rathore SS, Murthy HS, Nasren S, Mamun MAA, Rakesh K (2019) The role of vitamin c as growth promoter and its effect on intestinal histology in monosexnile tilapia, Oreochromis niloticus. J Exp Zool India 22:639-644.

76. Ren T, Koshio S, Uyan O, Komilus CF (2008) Effects of dietary vitamin C on blood chemistry and nonspecific immune response of juvenile red sea bream, Pagrus major. J World Aquacult Soc 39:797803. https://doi.org/10.1111/j.1749-7345.2008.00216.x

77. Ringoe E, Olsen RE, Mayhew TM, Myklebust R (2003) Electronmicroscopy of the intestinal microflora of fish. Aquacult 227:395-415. https://doi.org/10.1016/j.aquaculture.2003.05.001

78. Roosta Z, Hajimoradloo A, Ghorbani R, Hoseinifar SH (2014) The effects of dietary vitamin C on mucosal immune responses and growth performance in Caspian roach (Rutilus rutilus caspicus) fry. Fish Physiol Biochem 40:1601-1607. https://doi.org/10.1007/s10695-014-9951-6

79. Sabatini SE, Juarez AB, Eppis MR et al (2009) Oxidative stress and antioxidant defences in two green microalgae exposed to copper. Ecotoxicol Environ Saf 72:1200-1206. https://doi.org/10.1016/j.ecoenv.2009.01.003.

80. Saffari S, Keyvanshokooh S, Zakeri M, Johari SA, Pasha-Zanoosi H (2016) Effects of different dietary selenium sources (sodium selenite, selenomethionine and nanoselenim) on growth performance, muscle composition, blood enzymes and antioxidant status of common carp (cyprinus carpio). Aquac Nutr 23:611-617. https://doi.org/10.1111/anu.12428

81. Shafiei-Jahani P, Hurrell BPD et al (2020) R3 stimulation of adipose resident ILC2s ameliorates type 2 diabetes mellitus. Nat Commun 111-15. https://doi.org/10.1038/s41467-020-18601-7

82. Shao X, Liua W, Xu W et al (2010) Effects of dietary copper sources and levels on performance, copper status, plasma antioxidant activities and relative copper bioavailability in Carassius auratus gibelio. Aquacul 308:60-65. https://doi.org/10.1016/j.aquaculture.2010.07.021

83. Shaw BJ, Al-Bairuty G, Handy RD (2012) Effects of waterborne copper nanoparticles and copper sulphate on rainbow trout,(Oncorhynchus mykiss): physiology and accumulation. Aquat Toxicol 116:90-101. https://doi.org/10.1016/j.aquatox.2012.02.032 
84. Sheikh Asadi M, Gharaei A, Mirdar Harijani J, Arshadi A (2018) A Comparison between dietary effects of Cuminum cyminum essential oil and Cuminum cyminum essential oil, loaded with iron nanoparticles, on growth performance, immunity and antioxidant indicators of white leg shrimp (Litopenaeus vannamei). Aquac Nutr 24:1466-1473. https://doi.org/ 10.1111/anu.12683

85. Shiau SY, Ning YC (2003) Estimation of dietary copper requirements of juvenile tilapia, Oreochromis niloticus and O. aureus. Anim Sci J 77:287-292. https://doi.org/10.1017/S1357729800059026

86. Skadberg ESS (2015) Inflammatory effects in zebrafish (Danio rerio) exposed to gold nanoparticles. Master'sThesis in Toxicology.University of Oslo.

87. Srivastava PK, Pandey AK (2015) Role of Immunostimulants in immune responses of fish and shellfish. Biochem Cell Archiv 15:47-73.

88. Suska F, Esposito M, Gretzer $C$ et al (2003) IL-1a, IL-1 $\beta$ and TNF-a secretion during in vivo/ex vivo cellular interactions with titanium and copper. Biomaterials 24:461-468. https://doi.org/10.1016/S0142-9612(02)00359-9

89. Tang Q, Feng L, Jiang W D et al (2013) Effects of dietary copper on growth, digestive, and brush border enzyme activities and antioxidant defense of hepatopancreas and intestine for young grass carp (Ctenopharyngodon idella). Biol Trace Elem Res 155:370-380. https://doi.org/ 10.1007/s12011-0139785-6

90. Trenzado CE, Morales AE, Palma JM, de la Higuera M (2009) Blood antioxidant defenses and hematological adjustments in crowded/uncrowded rainbow trout (Oncorhynchus mykiss) fed on diets with different levels of antioxidant vitamins and HUFA. Comp Biochem Physiol 149:440-447. https://doi.org/10.1016/j.cbpc.2008.10.105

91. Valko M, Leibfritz D, Moncol $\mathrm{J}$ et al (2007) Free radicals and antioxidants in normal physiological functions and human disease. Int J Biochem Cell Biol 39:44-84. https://doi.org/10.1016/j.biocel.2006.07.001

92. Verlhac V, Gubaudan J (1994) Influence of vitamin C on the immune system of salmonids. Aquat Res 25:21-36. https://doi.org/10.1111/j.1365-2109.1994.tb00663.x

93. Wahli T, Verlhac V, Girling P, Gabaudan J, Aebischer C (2003) Influence of dietary vitamin C on the wound healing process in rainbow trout (Oncorhynchus mykiss). Aquacul 225:371-386. https://doi.org/10.1016/S0044-8486(03)00302-8

94. Wang T, Long $X$, Cheng $Y$ et al (2015) A comparison effect of copper nanoparticles versus copper sulphate on juvenile Epinephelus coioides: Growth parameters, digestive enzymes, body composition, and histology as biomarkers. Int J Genomics 7:1-10. https://doi.org/10.1155/2015/783021.

95. Wang W, Mai K, Zhang W et al (2009) Effects of dietary copper on survival, growth and immune response of juvenile abalone, Haliotis discus hannailno. Aquacul 297:122-127. https://doi.org/10.1016/j.aquaculture.2009.09.006

96. Watanabe T, Kiron V, Satoh S (1997) Trace minerals in fish nutrition. Aquacul 151:185-207. https://doi.org/10.1016/S0044-8486(96)01503-7

97. Watts DL (1989) The nutritional relationships of copper. J Orthomol Med 4:99-108. 
98. Xia J, Zhao HZ, Lu GH (2013) Effects of selected metal oxide nanoparticles on multiple biomarkers in Carassius auratus. Biomed Environ Sci 26:742-749. https://doi.org/10.3967/0895-3988.2013.09.005

99. Xie Z, Niu C, Zhang Z, Bao L (2006) Dietary ascorbic acid may be necessary for enhancing the immune response in Siberian sturgeon (Acipense rbaerii), a species capable of ascorbic acid biosynthesis. Comp Biochem Physiol A 145:152-157. https://doi.org/10.1016/j.cbpa.2006.05.015

100. Yano T (1992) Assays of hemolytic complement activity. Tech. Fish Immunol 131-141.

101. Yılmaz S, Ergün S (2018) Trans-Cinnamic Acid Application for RainbowTrout (Oncorhynchus mykiss): I. Effects on Haematological, Serum Biochemical, Non-Specific Immune and Head Kidney Gene Expression Responses. Fish Shellfish Immunol 78:140-157. https://doi.org/10.1016/j.fsi.2018.04.034

102. Yilmaz S, Ergün S, Yıgıt M (2018) Effects of Dietary FARMARIN® XP Supplement on Immunological Responses and Disease Resistance of Rainbow Trout (Oncorhynchus mykiss). Aquacult 496:211-220. https://doi.org/10.1016/j.aquaculture.2018.07.024

103. Yousefi P, Yavari V, Zakeri M, Salati A, Keyvanshokooh S (2013) Effect of dietary supplementation of vitamin $\mathrm{C}$ on growth performance feed utilization and carcass composition of Barbus sharpeyi fingerlings. J Persian Gul (Marine Science) 4:23-31.

104. Yun SH, Moon YS, Sohn SH, Jang IS (2012) Effects of cyclic heat stress or vitamin C supplementation during cyclic heat stress on HSP70, inflammatory cytokines, and the antioxidant defense system in Sprague Dawley rats. Exp Anim 61:543-553. https://doi.org/10.1538/expanim.61.543

105. Zhang J, Liu YJ, Tian LX et al (2013) Effects of dietary astaxanthin on growth, antioxidant capacity and gene expression in Pacific white shrimp Litopenaeus vannamei. Aquacul Nut19:917-927. https://doi.org/10.1111/anu.12037

106. Zhou Q, Wang L, Wang H, Xie F, Wang T (2012) Effect of dietary vitamin C on the growth performance and innate immunity of juvenile cobia (Rachycentron canadum). Fish Shellfish Immunol 32:969-975. https://doi.org/10.1016/j.fsi.2012.01.024

\section{Tables}

Table 1

The formulation of the basal diet 
Table 3

The real-time PCR primer sequences and thermocycling condition

\begin{tabular}{|c|c|c|c|c|}
\hline $\begin{array}{l}\text { Accession } \\
\text { no. }\end{array}$ & $\begin{array}{l}\text { Thermocycling } \\
\text { condition }\end{array}$ & Primer sequence $\left(5^{\prime}-3^{\prime}\right)$ & Primer & Genes \\
\hline \multirow[t]{2}{*}{ NM_001160614 } & \multirow{2}{*}{$\begin{array}{l}95 \circ \mathrm{C} 30 \mathrm{~s}, 35 \\
\text { cycles of } 95 \circ \mathrm{C} 5 \mathrm{~s}, \\
60.4 \circ \mathrm{C} 30 \mathrm{~s} \text { and } 72 \\
\circ \mathrm{C} 30 \mathrm{~s}\end{array}$} & GTAGTCGTGGCTCAATGGTAAG & $\mathrm{F}$ & \multirow[t]{2}{*}{ SOD } \\
\hline & & GCTTTATATTCTGCGGGTCATT & $\mathrm{R}$ & \\
\hline \multirow[t]{2}{*}{$110,490,868$} & \multirow{2}{*}{$\begin{array}{l}95 \circ \mathrm{C} 30 \mathrm{~s}, 35 \\
\text { cycles of } 95 \circ \mathrm{C} 5 \mathrm{~s}, \\
54.5 \circ \mathrm{C} 30 \mathrm{~s} \text { and } 72 \\
\circ \mathrm{C} 30 \mathrm{~s}\end{array}$} & TTGAGGTGACACATGACATCTCT & $\mathrm{F}$ & \multirow[t]{2}{*}{ CAT } \\
\hline & & ACGGTGGAGAAGCGAATGG & $\mathrm{R}$ & \\
\hline \multirow[t]{2}{*}{ AF281338 } & \multirow{2}{*}{$\begin{array}{l}95 \circ \mathrm{\circ} 30 \mathrm{~s}, 35 \\
\text { cycles of } 95 \circ \mathrm{C} 5 \mathrm{~s}, \\
60 \circ \mathrm{\circ} 30 \mathrm{~s} \text { and } 72 \\
\circ \mathrm{C} 30 \mathrm{~s}\end{array}$} & AAATTGCCATTCCCCTCCGA & $\mathrm{F}$ & \multirow[t]{2}{*}{ GPX } \\
\hline & & TCCATCAGGACTGACCAGGA & $\mathrm{R}$ & \\
\hline \multirow{2}{*}{$\begin{array}{l}\text { AJ223954 } \\
\text { AJ298294 }\end{array}$} & \multirow{2}{*}{$\begin{array}{l}95^{\circ \mathrm{C}} 30 \mathrm{~s}, 35 \text { cycles } \\
\text { of } 95^{\circ \mathrm{C}} 5 \mathrm{~s}, 62^{\circ \mathrm{C}} 30 \\
\mathrm{~s} \text { and } 72^{\circ \mathrm{C}} 30 \mathrm{~s}\end{array}$} & ACATTGCCAACCTCATCATCG & $\mathrm{F}$ & \multirow[t]{2}{*}{ IL-1 $\beta$} \\
\hline & & TTGAGCAGGTCCTTGTCCTTG & $\mathrm{R}$ & \\
\hline \multirow[t]{2}{*}{ AB118099 } & \multirow{2}{*}{$\begin{array}{l}95^{\circ \mathrm{C}} 30 \mathrm{~s}, 35 \text { cycles } \\
\text { of } 95^{\circ \mathrm{C}} 5 \mathrm{~s}, 60^{\circ \mathrm{C}} 30 \\
\mathrm{~s} \text { and } 72^{\circ \mathrm{C}} 30 \mathrm{~s}\end{array}$} & CGACTTTAAATCTCCCATCGAC & $\mathrm{F}$ & \multirow[t]{2}{*}{ IL-10 } \\
\hline & & GCATTGGACGATCTCTTTCTTC & $\mathrm{R}$ & \\
\hline \multirow[t]{2}{*}{ AJ249755.1 } & \multirow{2}{*}{$\begin{array}{l}95^{\circ \mathrm{C}} 30 \mathrm{~s}, 35 \text { cycles } \\
\text { of } 95^{\circ \mathrm{C}} 5 \mathrm{~s}, 60^{\circ \mathrm{C}} 30 \\
\mathrm{~s} \text { and } 72^{\circ \mathrm{C}} 30 \mathrm{~s}\end{array}$} & TGGAGGGGTATGCGATGACACCTG & $\mathrm{F}$ & \multirow[t]{2}{*}{ TNF-a } \\
\hline & & TGAGGCCTTTCTCTCAGCGACAGC & $\mathrm{R}$ & \\
\hline \multirow[t]{2}{*}{ AC006483.3 } & \multirow{2}{*}{$\begin{array}{l}95^{\circ \mathrm{C}} 30 \mathrm{~s}, 35 \text { cycles } \\
\text { of } 95^{\circ \mathrm{C}} 5 \mathrm{~s}, 60^{\circ \mathrm{C}} 30 \\
\mathrm{~s} \text { and } 72^{\circ \mathrm{C}} 30 \mathrm{~s}\end{array}$} & TCACCCACACTGTGCCCATCTACGA & $\mathrm{F}$ & \multirow[t]{2}{*}{$\begin{array}{l}\beta- \\
\text { Actin }\end{array}$} \\
\hline & & CAGCGGAACCGCTCATTGCCAATGG & $\mathrm{R}$ & \\
\hline
\end{tabular}

Table 4

The growth performance and nutrient digestibility of different experimental groups in the rainbow trout for 60 days (Means $\pm S E, n=3$ ). Means marked by different letters are significantly different $(p<0.05)$. 


\begin{tabular}{|c|c|c|c|c|c|}
\hline \multicolumn{6}{|c|}{ Parameters } \\
\hline $\begin{array}{l}\text { Trial diets(Cu- } \\
\left.\text { NPs/VC } \mathrm{mg} \mathrm{kg}^{-1}\right)\end{array}$ & WG\% & FCR & SGR\% & PER\% & $\mathrm{SR} \%$ \\
\hline $\mathrm{T} 1(0 / 0)$ & $159.24 \pm 7.83^{a}$ & $1.88 \pm 0.06^{\mathrm{a}}$ & $1.58 \pm 0.07^{a}$ & $120.52 \pm 13.43^{a}$ & $100 \pm 0.00$ \\
\hline T2 $(0 / 250)$ & $\begin{array}{l}182.04 \pm \\
10.09^{\mathrm{ab}}\end{array}$ & $1.66 \pm 0.1^{\mathrm{ab}}$ & $\begin{array}{l}1.72 \pm \\
0.05^{\mathrm{ab}}\end{array}$ & $\begin{array}{l}144.61 \pm \\
10.40^{\mathrm{ab}}\end{array}$ & $100 \pm 0.00$ \\
\hline T3 $(0 / 500)$ & $201.50 \pm 9.71^{b c}$ & $\begin{array}{l}1.41 \pm \\
0.03^{\mathrm{bc}}\end{array}$ & $\begin{array}{l}1.83 \pm \\
0.03^{\mathrm{bc}}\end{array}$ & $\begin{array}{l}167.46 \pm \\
6.39 \mathrm{bc}\end{array}$ & $100 \pm 0.00$ \\
\hline T4 $(2 / 250)$ & $247.96 \pm 8.53^{d}$ & $\begin{array}{l}1.24 \pm \\
0.03^{d}\end{array}$ & $2.07 \pm 0.08^{d}$ & $\begin{array}{l}191.54 \pm \\
10.86^{c}\end{array}$ & $100 \pm 0.00$ \\
\hline T5 $(2 / 500)$ & $\begin{array}{l}236.56 \pm \\
10.32^{\text {cd }}\end{array}$ & $\begin{array}{l}1.26 \pm \\
0.07^{d}\end{array}$ & $2.01 \pm 0.1^{c d}$ & $\begin{array}{l}188.69 \pm \\
15.76^{c}\end{array}$ & $100 \pm 0.00$ \\
\hline $\mathrm{T} 6(2 / 0)$ & $214.63 \pm 11.21^{\mathrm{bcd}}$ & $1.35 \pm 0.02^{b c}$ & $1.90 \pm 0.03^{\mathrm{bcd}}$ & $175.95 \pm 11.61^{c}$ & $97.22 \pm 0.33$ \\
\hline \multicolumn{6}{|c|}{ Two-way ANOVA (p-value), NS: not significant } \\
\hline Cu-NPs & $\mathrm{p}<0.05$ & $p<0.05$ & $p<0.05$ & $p<0.05$ & NS \\
\hline VC & NS & NS & NS & NS & NS \\
\hline Cu-NPs Í VC & NS & NS & NS & NS & NS \\
\hline
\end{tabular}

Table 5

The changes in immunological parameters in the juvenile rainbow trout at different experimental groups for 60 days (Means $\pm S E, n=3$ ). Means marked by different letters are significantly different $(p<0.05)$. 


\begin{tabular}{|c|c|c|c|c|c|c|}
\hline \multirow[t]{2}{*}{ Parameters } & \multicolumn{6}{|c|}{ Treatment groups (Cu-NPs/VC mg kg-1) } \\
\hline & $\mathrm{T} 1(0 / 0)$ & T2 (0/250) & T3 $(0 / 500)$ & T4 (2/250) & T5 (2/500) & T6 (2/0) \\
\hline $\begin{array}{l}\text { Lysozyme (U ml- } \\
\text { 1) }\end{array}$ & $50.2 \pm 2.1^{a}$ & $56.7 \pm 2.5^{\mathrm{a}}$ & $57.1 \pm 3.7^{a}$ & $85.0 \pm 4.5^{b}$ & $\begin{array}{l}100.6 \pm \\
5.9^{c}\end{array}$ & $58.4 \pm 2.6^{\mathrm{a}}$ \\
\hline $\mathrm{ACH} 50\left(\mathrm{U} \mathrm{ml}^{-1}\right)$ & $\begin{array}{l}125.2 \pm \\
1.3^{\mathrm{a}}\end{array}$ & $\begin{array}{l}137.9 \pm \\
3.2^{\mathrm{b}}\end{array}$ & $\begin{array}{l}140.3 \pm \\
2.3^{\mathrm{b}}\end{array}$ & $\begin{array}{l}153.4 \pm \\
4.1^{c}\end{array}$ & $\begin{array}{l}159.1 \pm \\
3.9^{c}\end{array}$ & $\begin{array}{l}134.9 \pm \\
3.8^{\mathrm{b}}\end{array}$ \\
\hline \multicolumn{7}{|c|}{ Two-way ANOVA (p-value), NS: not significant } \\
\hline Lysozyme & & \multicolumn{2}{|c|}{$\mathrm{ACH} 50$} & \multicolumn{2}{|l|}{ MDA } & \\
\hline Cu-NPs & $P<0.05$ & \multicolumn{2}{|c|}{$P<0.05$} & \multicolumn{2}{|l|}{ NS } & \\
\hline VC & NS & \multicolumn{2}{|l|}{ NS } & \multicolumn{2}{|l|}{ NS } & \\
\hline Cu-NPs Í VC & NS & \multicolumn{2}{|l|}{ NS } & \multicolumn{2}{|l|}{ NS } & \\
\hline
\end{tabular}

Table 6

The changes in antioxidant capacity parameters in the juvenile rainbow trout at different experimental groups for 60 days (Means $\pm S E, n=3$ ). Means marked by different letters are significantly different $(p<$ 0.05). 


\begin{tabular}{|c|c|c|c|c|c|c|}
\hline \multirow[t]{2}{*}{ Parameters } & \multicolumn{6}{|c|}{ Treatment groups (Cu-NPs/VC mg kg-1) } \\
\hline & $\mathrm{T} 1(0 / 0)$ & T2 (0/250) & T3 $(0 / 500)$ & $\mathrm{T} 4(2 / 250)$ & $\begin{array}{l}\text { T5 } \\
(2 / 500)\end{array}$ & T6 (2/0) \\
\hline $\operatorname{SOD}\left(\mathrm{U} \mathrm{ml}^{-1}\right)$ & $\begin{array}{l}65.33 \pm \\
2.28^{a}\end{array}$ & $\begin{array}{l}62.21 \pm \\
3.20^{\mathrm{ab}}\end{array}$ & $\begin{array}{l}53.63 \pm \\
2.91^{\mathrm{b}}\end{array}$ & $\begin{array}{l}45.81 \pm \\
3.62^{\mathrm{c}}\end{array}$ & $\begin{array}{l}42.13 \pm \\
1.97^{c}\end{array}$ & $\begin{array}{l}59.11 \pm \\
2.81^{\mathrm{ab}}\end{array}$ \\
\hline $\operatorname{CAT}\left(\mathrm{U} \mathrm{ml}^{-1}\right)$ & $\begin{array}{l}145.67 \pm \\
12.8^{\mathrm{a}}\end{array}$ & $\begin{array}{l}141.0 \pm \\
9.53^{\mathrm{a}}\end{array}$ & $\begin{array}{l}120.66 \pm \\
8.96^{\mathrm{a}}\end{array}$ & $\begin{array}{l}112.0 \pm \\
11.26^{\mathrm{b}}\end{array}$ & $\begin{array}{l}113.5 \pm \\
7.47^{b}\end{array}$ & $\begin{array}{l}146.3 \pm \\
6.50^{\mathrm{a}}\end{array}$ \\
\hline $\mathrm{GPX}\left(\mathrm{U} \mathrm{ml}^{-1}\right)$ & $\begin{array}{l}680.52 \pm \\
17.3^{a}\end{array}$ & $\begin{array}{l}692.66 \pm \\
18.1^{\mathrm{a}}\end{array}$ & $\begin{array}{l}601.5 \pm \\
14.0^{\mathrm{ab}}\end{array}$ & $\begin{array}{l}573.30 \pm \\
21.2^{\mathrm{b}}\end{array}$ & $\begin{array}{l}559.4 \pm \\
23.4^{\mathrm{b}}\end{array}$ & $\begin{array}{l}673.71 \pm \\
25.7^{\mathrm{a}}\end{array}$ \\
\hline $\begin{array}{l}\mathrm{MDA}(\mu \mathrm{mol} \\
\left.\mathrm{ml}^{-1}\right)\end{array}$ & $57 \pm 6.1$ & $56.4 \pm 4.9$ & $58.3 \pm 5.03$ & $56.6 \pm 4.7$ & $\begin{array}{l}55.6 \pm \\
5.15\end{array}$ & $58.3 \pm 4.2$ \\
\hline \multicolumn{7}{|c|}{ Two-way ANOVA (p-value), NS: not significant } \\
\hline SOD & & & \multicolumn{2}{|l|}{ CAT } & \multicolumn{2}{|c|}{ GPX } \\
\hline Cu-NPs & \multicolumn{2}{|c|}{ NS } & \multicolumn{2}{|c|}{$P<0.05$} & \multicolumn{2}{|c|}{$P<0.05$} \\
\hline VC & \multicolumn{2}{|c|}{$P<0.05$} & \multicolumn{2}{|l|}{ NS } & \multicolumn{2}{|c|}{ NS } \\
\hline Cu-NPs I VC & \multicolumn{2}{|c|}{$P<0.05$} & \multicolumn{2}{|l|}{ NS } & \multicolumn{2}{|c|}{ NS } \\
\hline
\end{tabular}

Table 7

The hematological parameters of the rainbow trout juveniles in different experimental groups for 60 days (Means $\pm S E, n=3$ ). Means marked by different letters are significantly different $(p<0.05)$ 


\begin{tabular}{|c|c|c|c|c|c|c|c|}
\hline \multicolumn{8}{|c|}{ Parameters } \\
\hline Trial diets & RBC & WBC & $\mathrm{Hb}$ & $\mathrm{Hct}$ & MCV & $\mathrm{MCH}$ & $\mathrm{MCHC}$ \\
\hline $\begin{array}{l}\text { (Cu-NPs/VC mg } \\
\mathrm{kg}^{-1} \text { ) }\end{array}$ & $\begin{array}{l}\left(10^{6}\right. \\
\left.\mathrm{mm}^{-3}\right)\end{array}$ & $\begin{array}{l}\left(110^{3}\right. \\
\left.\mathrm{mm}^{-3}\right)\end{array}$ & $\left(\mathrm{g} \mathrm{dl}^{-1}\right)$ & $(\%)$ & (fl) & $(\mathrm{pg})$ & $\left(\mathrm{g} \mathrm{dl}^{-1}\right)$ \\
\hline $\mathrm{T} 1(0 / 0)$ & $\begin{array}{l}1.03 \pm \\
0.31\end{array}$ & $\begin{array}{l}52.3 \pm \\
5.7\end{array}$ & $\begin{array}{l}5.55 \pm \\
0.2^{\mathrm{a}}\end{array}$ & $\begin{array}{l}38.6 \pm \\
2.1^{\mathrm{ab}}\end{array}$ & $\begin{array}{l}357.4 \pm \\
5.8^{\mathrm{b}}\end{array}$ & $\begin{array}{l}53.8 \pm \\
8.1\end{array}$ & $\begin{array}{l}14.4 \pm \\
0.4\end{array}$ \\
\hline T2 (0/250) & $\begin{array}{l}1.1 \pm \\
0.12\end{array}$ & $\begin{array}{l}51.1 \pm \\
6.8\end{array}$ & $\begin{array}{l}5.6 \pm \\
0.51^{\mathrm{a}}\end{array}$ & $\begin{array}{l}40.6 \pm \\
6.6^{\mathrm{ab}}\end{array}$ & $\begin{array}{l}369.1 \pm \\
13.7^{b}\end{array}$ & $\begin{array}{l}50.9 \pm \\
7.3\end{array}$ & $\begin{array}{l}13.8 \pm \\
1.5\end{array}$ \\
\hline T3 $(0 / 500)$ & $\begin{array}{l}0.98 \pm \\
0.15\end{array}$ & $\begin{array}{l}52.4 \pm \\
5.9\end{array}$ & $\begin{array}{l}5.6 \pm \\
0.36^{a}\end{array}$ & $\begin{array}{l}35.6 \pm \\
4.3^{\mathrm{a}}\end{array}$ & $\begin{array}{l}363.2 \pm \\
14.2^{\mathrm{b}}\end{array}$ & $\begin{array}{l}57.1 \pm \\
9.2\end{array}$ & $\begin{array}{l}15.7 \pm \\
1.2\end{array}$ \\
\hline $\mathrm{T} 4(2 / 250)$ & $\begin{array}{l}1.1 \pm \\
0.28\end{array}$ & $\begin{array}{l}49.7 \pm \\
4.7\end{array}$ & $\begin{array}{l}6.2 \pm \\
0.15^{b}\end{array}$ & $\begin{array}{l}42.0 \pm \\
1.2^{\mathrm{a}}\end{array}$ & $\begin{array}{l}381.8 \pm \\
21.1^{a}\end{array}$ & $\begin{array}{l}56.4 \pm \\
4.5\end{array}$ & $\begin{array}{l}14.8 \pm \\
0.8\end{array}$ \\
\hline T5 $(2 / 500)$ & $\begin{array}{l}1.12 \pm \\
0.16\end{array}$ & $\begin{array}{l}50.3 \pm \\
4.9\end{array}$ & $\begin{array}{l}6.4^{ \pm} \\
0.4^{\mathrm{b}}\end{array}$ & $\begin{array}{l}43.6 \pm \\
3.0^{\mathrm{a}}\end{array}$ & $\begin{array}{l}389.3 \pm \\
25.5^{\mathrm{a}}\end{array}$ & $\begin{array}{l}57.1 \pm \\
6.8\end{array}$ & $\begin{array}{l}14.7 \pm \\
1.5\end{array}$ \\
\hline T6 (2/0) & $\begin{array}{l}1.11 \pm \\
0.10\end{array}$ & $\begin{array}{l}49.6 \pm \\
5.3\end{array}$ & $\begin{array}{l}5.75 \pm \\
0.3^{\mathrm{a}}\end{array}$ & $\begin{array}{l}41.0 \pm \\
4.5^{\mathrm{ab}}\end{array}$ & $\begin{array}{l}369.4 \pm \\
12.6^{\mathrm{b}}\end{array}$ & $\begin{array}{l}51.8 \pm \\
6.3\end{array}$ & $\begin{array}{l}14.0 \pm \\
0.7\end{array}$ \\
\hline \multicolumn{8}{|c|}{ Two-way ANOVA (p-value), NS: not significant } \\
\hline Cu-NPs & NS & NS & NS & $P<0.05$ & $P<0.05$ & NS & NS \\
\hline VC & NS & NS & $p<0.05$ & NS & NS & NS & NS \\
\hline Cu-NPs Í VC & NS & NS & $p<0.05$ & NS & NS & NS & NS \\
\hline
\end{tabular}


Table 8

The relative mRNA levels of the rainbow trout intestine at different experimental groups for 60 days (Means $\pm S E, n=5)$. Means marked by different letters are significantly different $(p<0.05)$.

Trial diets

Genes

(Cu-NPs/VC mg kg-1)

$\begin{array}{lllllll}\text { T6 (2/0) } & \text { T5 }(2 / 500) & \text { T4 }(2 / 250) & \text { T3 }(0 / 500) & \text { T2 }(0 / 250) & \text { T1 }(0 / 0) & \\ 1.67 \pm 0.23^{\mathrm{a}} & 0.84 \pm 0.06^{\mathrm{c}} & 1.07 \pm 0.14^{\mathrm{b}} & 1.15 \pm 0.08^{\mathrm{b}} & 1.52 \pm 0.12^{\mathrm{a}} & 1.41 \pm 0.11^{\mathrm{a}} & \begin{array}{l}\text { TNF- } \\ \mathrm{a}\end{array}\end{array}$

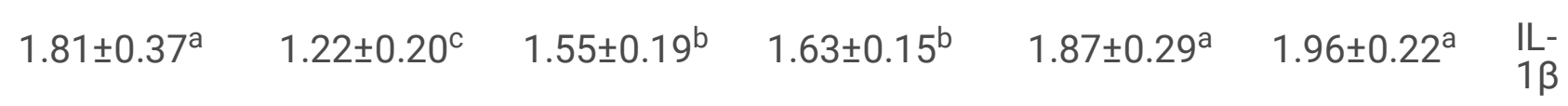

$\begin{array}{lllllll}1.97 \pm 0.38^{\mathrm{a}} & 1.1 \pm 0.09^{\mathrm{b}} \quad 1.24 \pm 0.85^{\mathrm{b}} \quad 1.72 \pm 0.54^{\mathrm{ab}} \quad 1.92 \pm 0.41^{\mathrm{a}} & 2.07 \pm 0.23^{\mathrm{a}} \quad I L- & 10\end{array}$

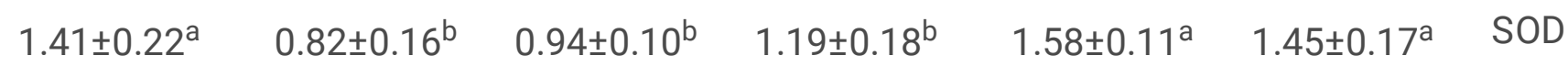

$\begin{array}{ccccccc}1.49 \pm 0.17^{\mathrm{ab}} & 1.12 \pm 0.19^{\mathrm{b}} & 1.31 \pm 0.17^{\mathrm{b}} & 1.28 \pm 0.07^{\mathrm{b}} & 1.68 \pm 0.22^{\mathrm{a}} & 1.91 \pm 0.28^{\mathrm{a}} & \text { CAT } \\ 2.05 \pm 0.33^{\mathrm{a}} & 1.07 \pm 0.21^{\mathrm{b}} & 1.19 \pm 0.18^{\mathrm{b}} & 1.75 \pm 0.21^{\mathrm{ab}} & 2.15 \pm 0.36^{\mathrm{a}} & 2.11 \pm 0.72^{\mathrm{a}} & \text { GPX }\end{array}$

Figures

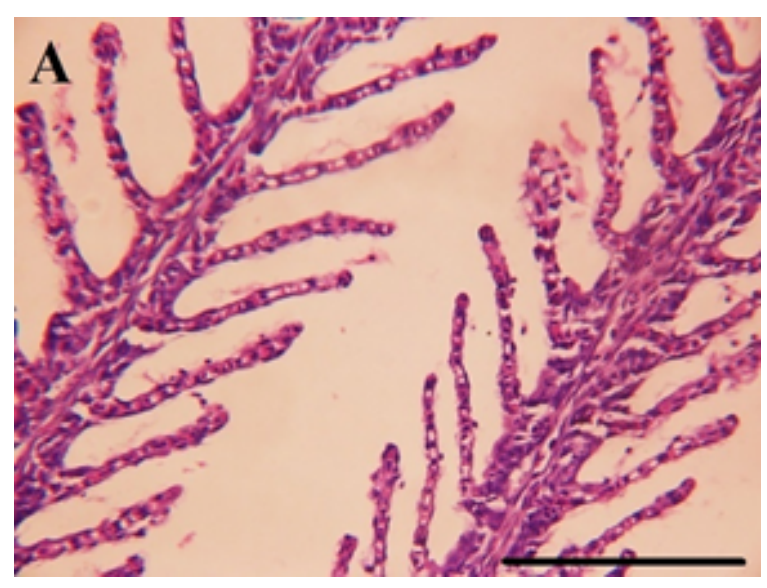

Figure 1

Tissue sections of gills in rainbow trout. (A). Control group (H\&E, scale bar= $185 \mu \mathrm{m})$. 


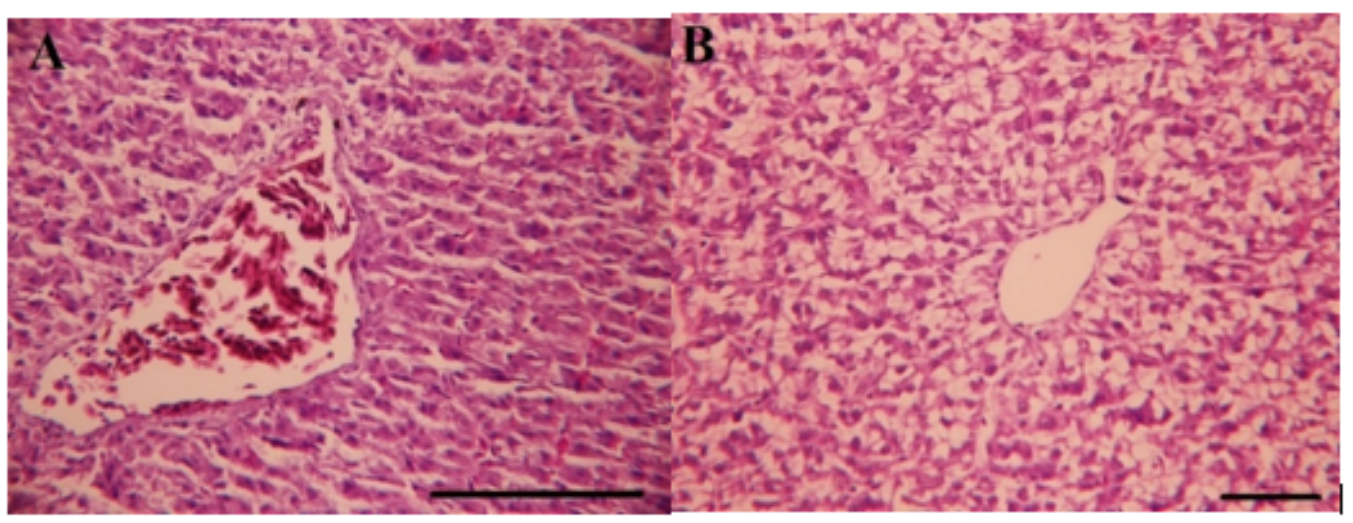

Figure 2

Tissue sections of the liver in rainbow trout. (A): Control group (H\&E, scale bar= $150 \mu \mathrm{m})$. (B):(H\&E, scale bar $=50 \mu \mathrm{m})$.

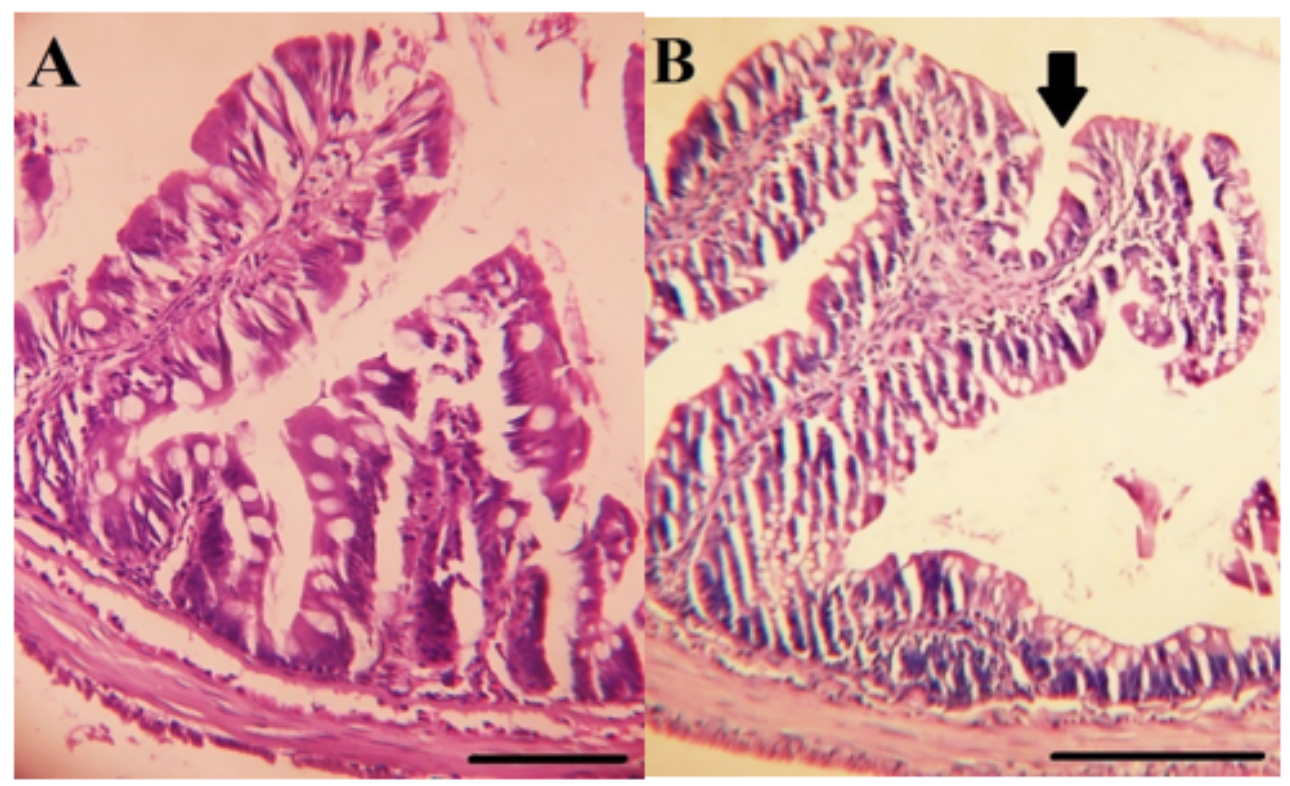

\section{Figure 3}

Tissue sections of the intestine in rainbow trout. (A): (H\&E, scale bar $=140 \mu \mathrm{m})$. (B): (H\&E, scale bar= 100 $\mu \mathrm{m})$. 


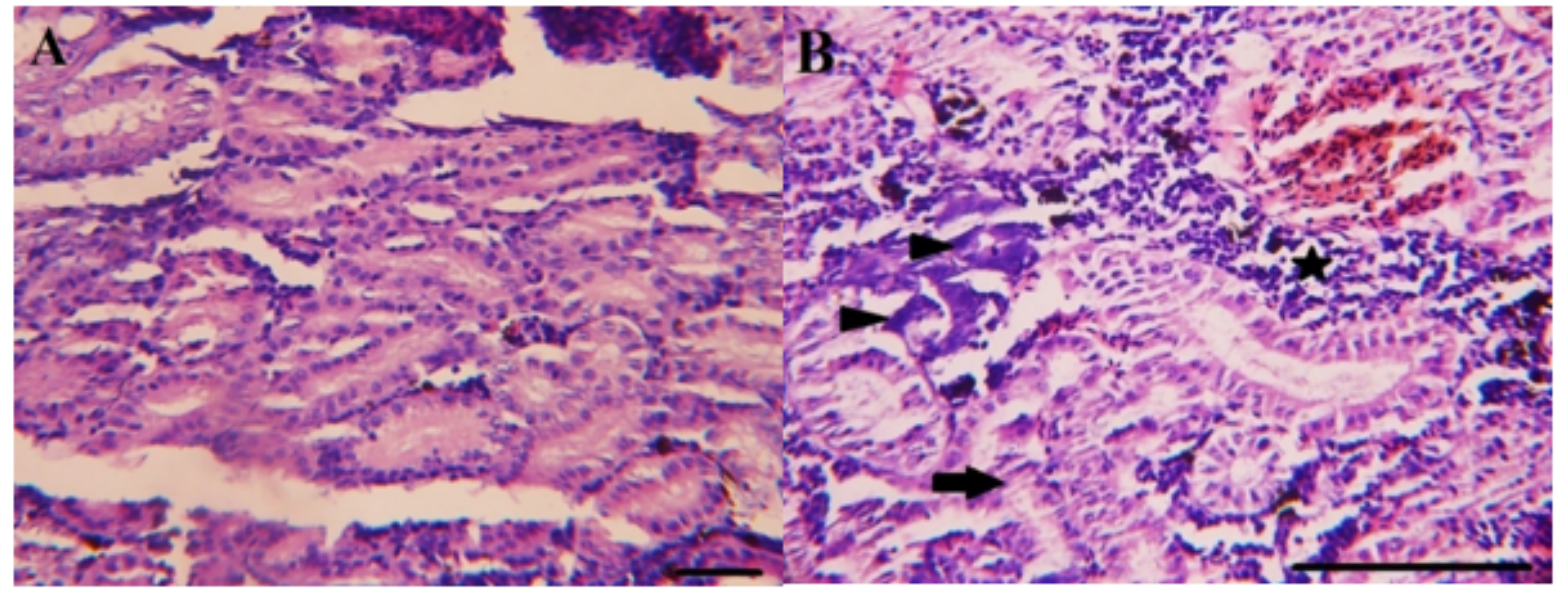

\section{Figure 4}

Tissue sections of the kidneys in rainbow trout. (A): (H\&E, scale bar= $100 \mu \mathrm{m})$. (B): (arrowheads) (H\&E, scale bar= $125 \mu \mathrm{m})$.

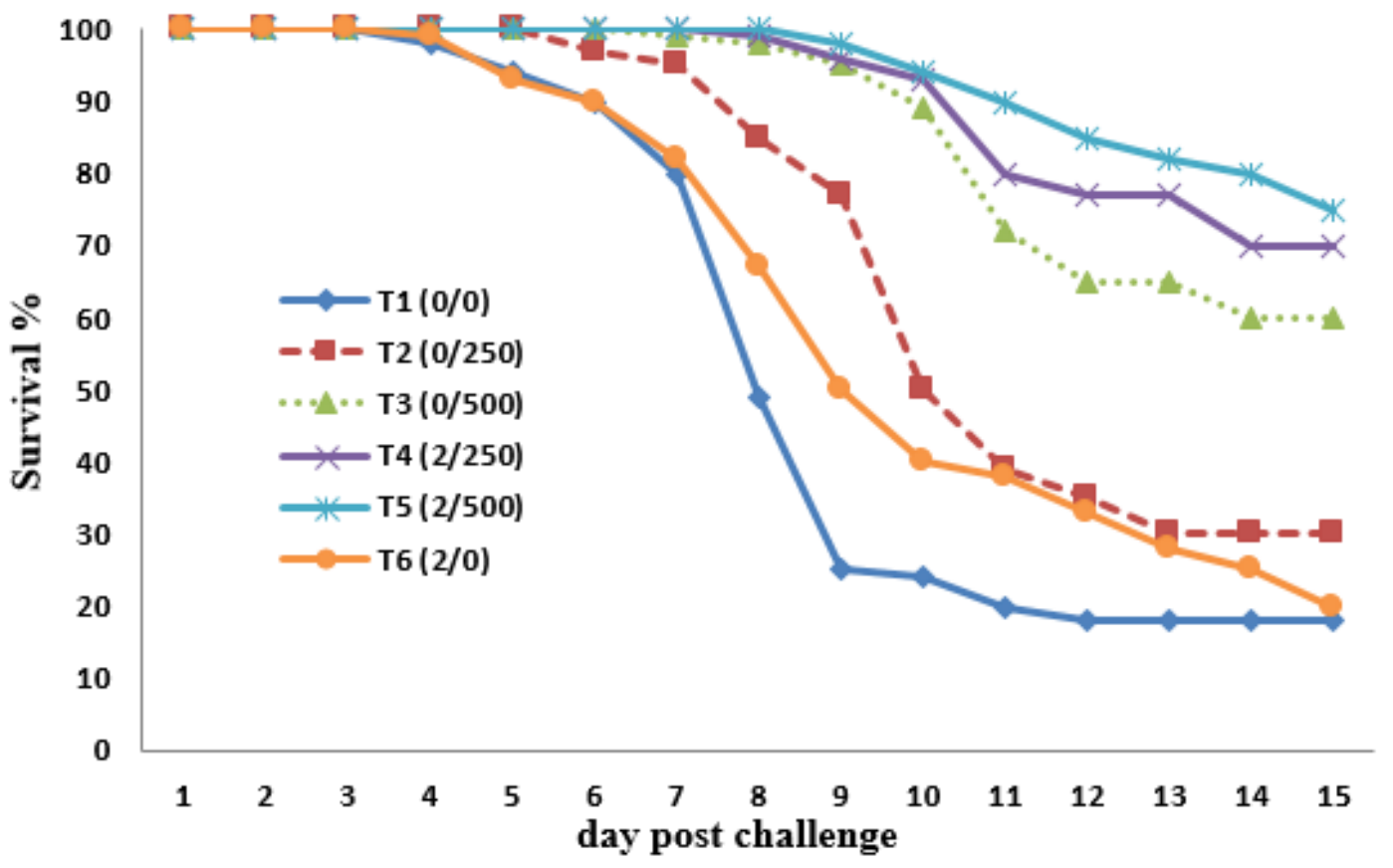

\section{Figure 5}

The survival rate of rainbow trout fed on different doses of dietary Cu-NPs and/or VC (Cu-NPs/VC mg kg-1) supplementation during 15-day post-challenge with Yersinia ruckeri. 